\title{
Early coagulation tests predict risk stratification and prognosis of COVID-19
}

\author{
Lili Luo ${ }^{1,2, *}$, Min $\mathrm{Xu}^{1,2,{ }^{*}}$, Mengyi Du ${ }^{1,2, *}$, Haiming Kou ${ }^{1,2}$, Danying Liao ${ }^{1,2}$, Zhipeng Cheng ${ }^{1,2}$, Heng \\ $\mathrm{Mei}^{1,2}, \mathrm{Yu} \mathrm{Hu}{ }^{1,2}$ \\ ${ }^{1}$ Institute of Hematology, Union Hospital, Tongji Medical College, Huazhong University of Science and Technology, \\ Wuhan 430022, China \\ ${ }^{2}$ Hubei Clinical and Research Centre of Thrombosis and Hemostasis, Wuhan 430022, China \\ *Co-first authors
}

Correspondence to: Heng Mei, Yu Hu; email: hmei@hust.edu.cn, huvu whuh@hust.edu.cn

Keywords: COVID-19, blood coagulation disorders, risk, prognosis, meta-analysis

Received: April 28, 2020

Accepted: June 9, 2020

Published: August 29, 2020

Copyright: Luo et al. This is an open-access article distributed under the terms of the Creative Commons Attribution License (CC BY 3.0), which permits unrestricted use, distribution, and reproduction in any medium, provided the original author and source are credited.

\section{ABSTRACT}

The ongoing outbreak of Coronavirus Disease 2019 (COVID-19) is hitting the world hard, but the relationship between coagulation disorders and COVID-19 is still not clear. This study aimed to explore whether early coagulation tests can predict risk stratification and prognosis. PubMed, Web of Science, Cochrane Library, and Scopus were searched electronically for relevant research studies published up to March 24, 2020, producing 24 articles for the final inclusion. The pooled standard mean difference (SMD) of coagulation parameters at admission were calculated to determine severe and composite endpoint conditions (ICU or death) in COVID-19 patients. Meta-analyses revealed that platelet count was not statistically related to disease severity and composite endpoint; elevated D-dimer correlated positively with disease severity (SMD 0.787 (0.277-1.298), $P=0.003, I^{2}=$ 96.7\%) but had no significant statistical relationship with composite endpoints. Similarly, patients with prolonged prothrombin time (PT) had an increased risk of ICU and increased risk of death (SMD 1.338 (0.551-2.125), P = 0.001, $I^{2}=92.7 \%$ ). Besides, increased fibrin degradation products (FDP) and decreased antithrombin might also mean the disease is worsening. Therefore, early coagulation tests followed by dynamic monitoring is useful for recognizing coagulation disorders accompanied by COVID-19 and guiding timely therapy to improve prognosis.

\section{INTRODUCTION}

In December 2019, a group of patients with unexplained pneumonia in Wuhan, China was found to be infected with a previously unknown coronavirus, officially named later as Coronavirus Disease 2019 (COVID-19). The coronavirus was initially called $2019-\mathrm{nCoV}$ but was subsequently renamed severe acute respiratory syndrome coronavirus 2 (SARS-Cov-2) because it has $75-80 \%$ genomic similarity to SARS-CoV and 50\% resemblance to the Middle East Respiratory Syndrome coronavirus (MERS-CoV) [1]. SARS-CoV2 is the third known kind of coronavirus that causes severe acute respiratory distress syndrome (ARDS) in humans, the others being SARS$\mathrm{CoV}$ and MERS-CoV. As of April 7, 2020, 1,342,184 cases have been confirmed worldwide. Although the fatality rate will continue to change until all infected persons have recovered, it appears that SARS-CoV2 is less deadly (approximately 3.7\%) than SARS-CoV $(\sim 10 \%)$ and much less than MERS-CoV $(\sim 40 \%)[2,3]$. Regrettably, the outbreak of COVID-19 is spreading wide and amplifying mainly because of the long incubation period and high infection rates, raising great public health concerns globally. 
Unfortunately, some studies have revealed that mortality rates in critical COVID-19 patients are high $(\sim 41.7 \%)$, possibly because of the association of the disease with severe complications, including organ failure, sepsis/septic shock, and sepsis-associated coagulopathy [4-11]. Generally, the three conditions mentioned above are complexly linked in critical patients. Sepsis is consistently common in severe patients with SARS-CoV2 infection as a secondary disease [5]. Septic shock and sepsis-associated coagulopathy are severe conditions of sepsis, both of which can result in organ failure. The early reported incidence of at least one organ dysfunction is about $30 \% \sim 60 \%$ in critically ill patients and non-survivors $[5$, $6,12,13]$, while the reported incidence of shock varies from $23 \%$ to $70 \%[5,6,13]$. However, coagulopathy in COVID-19 has been reported rarely; only three articles have mentioned this problem up to now.

In the first report of the occurrence of disseminated intravascular coagulation (DIC), the worst form of coagulopathy, in a large epidemiological study on COVID- 19 , only $0.6 \%$ of the patients with severe cases had DIC; the standard used for diagnosis was not mentioned, and no one had DIC among non-severe patients [8]. Tang's analysis focusing on abnormal coagulation parameters revealed that $71.4 \%(15 / 21)$ of non-survivors with COVID-19 met the criteria for overtDIC [11]. Zhou and his colleagues later found that $50 \%$ of non-survivors with COVID-19 had coagulopathy, and only $7 \%$ of survivors had coagulopathy [5]. However, DIC encompasses a broad spectrum of clinical manifestations, ranging from a prothrombotic state to bleeding or both [14], and there is a lack of a golden approach to diagnosing DIC, easily leading to misdiagnosis and missed diagnoses. To optimize patient care and resource allocation during this pandemic, coagulation parameters reflecting coagulopathy and DIC are urgently needed for risk stratification and for actively monitoring illness severity.

Abnormal coagulation parameters reflecting coagulopathy, including platelet count, D-dimer level, prothrombin time (PT), and activated partial thromboplastin time (APTT), are common in many COVID-19 patients at admission. However, these indicators, as presented in different articles, are providing contradictory messages to guiding risk stratification and predicting outcomes. Although two independent teams have shown that severe COVID-19 patients have significantly lower platelet counts than non-severe patients $[10,15]$, other teams have demonstrated that there is no significant difference between the two groups $[6,7$, 13, 16-18]. Almost all related articles have reported that critical or non-survivor patients had statistically significantly higher levels of D-dimer than non-severe or survivor patients [4, 6, 10, 19-22], except for one [15]. PT is more prolonged in severe patients in some articles [6, $10,11]$, but not so in other reports $[4,13,19,23]$. APTT in severe COVID-19 patients appears more complicated, longer than in non-severe patients [10] or shorter than in non-severe patients $[4,21]$ or similar to the one in nonsevere patients $[6,11,13,23,24]$. Some reports have shown that there is no significant difference in fibrinogen levels between severe COVID-19 patients and non-severe patients [11, 17, 19], but one article found higher levels in severe patients [23]. Therefore, we did a meta-analysis and a systematic review to comprehensively analyze the significance of early coagulation tests and understand coagulopathy during COVID-19 progression for disease stratification and prediction of the composite endpoint (ICU admission or death).

\section{RESULTS}

\section{The outcome of the electronic search}

Overall, 3370 documents were initially identified based on our search criteria and a reference list (Figure 1). Subsequently, 1669 files were excluded because of duplication, and 1627 were excluded after reading the title and abstract and finding that the materials were not related to medicine $(\mathrm{n}=488)$ or failed to report clinical characteristics or laboratory tests $(n=657)$ or that they were reviews $(\mathrm{n}=271)$, or expert consensus $(\mathrm{n}=96)$, meta-analyses $(\mathrm{n}=9)$, or case reports $(\mathrm{n}=74)$. Additionally, 32 documents relating to children were excluded. As a result, 74 articles were selected for full-text assessment. Of the 74 studies, 50 were disqualified for lacking information on coagulation test data $(\mathrm{n}=34)$, or having no definition of disease severity $(\mathrm{n}=12)$, or lacking descriptive summary analyses $(\mathrm{n}=3)$, or being a review (n $=1$ ). In the end, 24 articles were included for the metaanalysis. To eliminate bias, the detailed endpoint was split into severity and composite endpoint instead of a rough poor outcome. Also, we analyzed several biomarkers individually rather than treat them as one entity.

\section{Characteristics of the 24 selected studies}

Of the articles included, 23 were full-length articles published in peer-reviewed journals, and one article was provided by the corresponding author after we reached out to them. Most of the studies were from China ( $\mathrm{n}=$ 22), except for two from Singapore. All the investigations were case-control trials assessing 3544 adult COVID-19 patients; the sample size of each study varied from 21 to 1099 participants. The vast majority of patients were diagnosed using laboratory nucleic acid tests, except for three patients who were diagnosed based on clinical characteristics and imaging data. The details of the selected studies are provided in Table 1. 
Ottawa quality assessment scale (NOS) was used to evaluate the quality of the chosen literature, and all literature scored $\geq 8$ points (Supplementary Table 1), indicating that the quality of each of the 24 studies was high.

\section{The relationship between platelets and disease severity or composite endpoint}

The relationship between disease prognosis and platelets was analyzed in 16 articles with 2980 COVID-19 patients (Table 2). Of the 16 articles, 12 studies with 2152 patients were used to analyze the relationship between platelets and disease severity, $[7,8,10,12,15$, $17,18,22,25-27]$ and 1778 patients in 6 articles were used to analyze the relationship between platelets and composite endpoint $[6,8,12,13,16]$. Pooled analyses revealed that platelet count was not statistically linked to disease severity (standard mean difference (SMD) -0.271 (-0.547-0.005), $\left.P=0.054, I^{2}=84.6 \%\right)$ and composite endpoint (SMD -0.541 (-1.109-0.028), $P=0.062, I^{2}=$ $92.5 \%$ ) on admission (Table 2, Figures 2 and 3). Because the heterogeneity value was over $50 \%$, the random effect model was used for the meta-analysis of these articles.

\section{The relationship between D-dimer and disease severity or composite endpoint}

In this meta-analysis, we explored the relationship between D-dimer and prognosis in 1762 patients with
COVID-19 from 13 investigations (Table 2). Based on the data from 1438 participants in 11 trials, $[4,10,15$, $17,19,20,22,23,25,28]$.

We found that D-dimer correlated positively with disease severity in patients with COVID-19 (SMD 0.787 (0.277-1.298), $P=0.003, I^{2}=96.7 \%$ ), suggesting that D-dimer levels were significantly elevated in critically ill patients. Also, 410 patients in three articles were assessed for the relationship between D-dimer and composite endpoint $[5,13]$, but we found no statistical relationship between the two parameters (SMD 1.523 (0.221-3.267), $P=0.0087, I^{2}=97.5 \%$ ), see Table 2, Figures 2 and 3.

\section{The relationship between PT and disease severity or composite endpoint}

Eleven articles with 1641 patients were analyzed for PT; 7 articles with 940 cases were evaluated for the relationship between PT and disease severity $[4,10,19$, 21, 23], and 5 articles with 645 cases were examined for the relationship between PT and composite endpoint [5, 11-13]. The analyses showed that prolonged PT during admission indicated a more serious disease, with the two correlating positively (SMD 0.803 (0.254-1.352), $P$ $\left.=0.004, I^{2}=91.3 \%\right)$. Similarly, patients with prolonged PT had an increased risk of ICU during admission and increased risk of death (SMD $1.338(0.551-2.125), P=$ $0.001, I^{2}=92.7 \%$ ), see Table 2, Figures 2 and 3 .

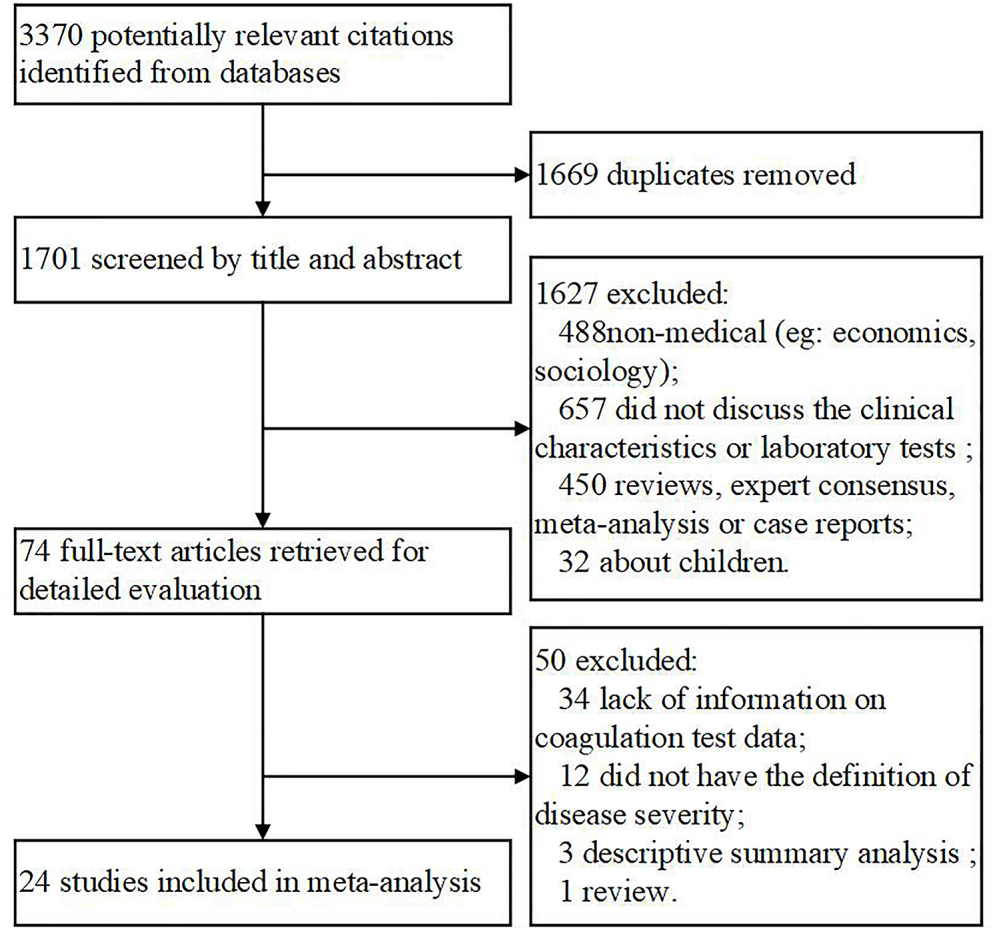

Figure 1. Flow chart of the included studies. 
Table 1. Basic information of included studies.

\begin{tabular}{|c|c|c|c|c|c|c|c|c|c|c|c|}
\hline Num & $\begin{array}{l}\text { Study } \\
\text { cohort }\end{array}$ & Journal & Institute/region & Period & Follow-up & $\begin{array}{c}\text { Study } \\
\text { type }\end{array}$ & No.(M/F) & Diagnose & Age (year) & $\begin{array}{c}\text { Compared } \\
\text { endpoint }\end{array}$ & NOS \\
\hline 1 & $\mathrm{Cao} \mathrm{B}^{6}$ & Lancet & $\begin{array}{c}\text { Jinyintan Hospital \& } \\
\text { Wuhan Pulmonary Hospital }\end{array}$ & $\begin{array}{c}2019 / 12 / 29- \\
2020 / 1 / 31\end{array}$ & NA & $\begin{array}{c}\text { case } \\
\text { control }\end{array}$ & $\begin{array}{c}191 \\
(119 / 72)\end{array}$ & $\begin{array}{l}\text { laboratory- } \\
\text { confirmed }\end{array}$ & $-\frac{56.0}{(46.0-67.0)}$ & composite endpoint & 8 \\
\hline 2 & Sun $Z Y^{11}$ & $\begin{array}{c}\text { J. Thromb. } \\
\text { Hemost. }\end{array}$ & Tongji Hospital & $\begin{array}{l}2020 / 1 / 1- \\
2020 / 2 / 3\end{array}$ & $2020 / 2 / 13$ & $\begin{array}{c}\text { case } \\
\text { control }\end{array}$ & $\begin{array}{c}183 \\
(98 / 85)\end{array}$ & $\begin{array}{l}\text { laboratory- } \\
\text { confirmed }\end{array}$ & $54.1(14-94)$ & composite endpoint & 8 \\
\hline 3 & Cao B (2) ${ }^{5}$ & Lancet & Jinyintan Hospital & $\begin{array}{l}2019 / 12 / 16 \\
-2020 / 1 / 2\end{array}$ & $2020 / 1 / 22$ & $\begin{array}{c}\text { case } \\
\text { control }\end{array}$ & $41(30 / 11)$ & $\begin{array}{l}\text { laboratory- } \\
\text { confirmed }\end{array}$ & $\begin{array}{c}49.0(41 \cdot 0- \\
58.0)\end{array}$ & composite endpoint & 8 \\
\hline 4 & Ning $Q^{21}$ & NA & Tongji Hospital & $\begin{array}{c}\text { 2019/12/19- } \\
2020 / 1 / 27\end{array}$ & $2020 / 2 / 2$ & $\begin{array}{c}\text { case } \\
\text { control }\end{array}$ & $21(17 / 4)$ & $\begin{array}{l}\text { laboratory- } \\
\text { confirmed }\end{array}$ & $\begin{array}{c}56.3 \\
(42.0-70.6)\end{array}$ & severity status & 8 \\
\hline 5 & Peng $Z Y^{13}$ & JAMA & Zhongnan Hospital & $\begin{array}{l}2020 / 1 / 1- \\
2020 / 1 / 28\end{array}$ & $2020 / 2 / 3$ & $\begin{array}{c}\text { case } \\
\text { control }\end{array}$ & $\begin{array}{c}138 \\
(75 / 63)\end{array}$ & $\begin{array}{l}\text { laboratory- } \\
\text { confirmed }\end{array}$ & $56(42-68)$ & composite endpoint & 8 \\
\hline 6 & $\begin{array}{c}\text { Zhong NS } \\
8\end{array}$ & NA & 552 hospitals & $2020 / 1 / 29$ & $2020 / 1 / 29$ & $\begin{array}{c}\text { case } \\
\text { control }\end{array}$ & $\begin{array}{c}1099 \\
(640 / 459)\end{array}$ & $\begin{array}{l}\text { laboratory- } \\
\text { confirmed }\end{array}$ & $\begin{array}{c}47.0 \\
(35.0-58.0)\end{array}$ & $\begin{array}{c}\text { severity } \\
\text { status/composite } \\
\text { endpoint }\end{array}$ & 8 \\
\hline 7 & Song $\mathrm{YL}^{2}$ & $\begin{array}{l}\text { JAMA Internal } \\
\text { Medicine }\end{array}$ & Jinyintan Hospital & $\begin{array}{c}2019 / 12 / 24- \\
2020 / 1 / 26\end{array}$ & $2020 / 2 / 13$ & $\begin{array}{c}\text { case } \\
\text { control }\end{array}$ & $\begin{array}{c}201 \\
(128 / 73)\end{array}$ & $\begin{array}{l}\text { laboratory- } \\
\text { confirmed }\end{array}$ & $51(43-60)$ & $\begin{array}{c}\text { severity } \\
\text { status/composite } \\
\text { endpoint }\end{array}$ & 8 \\
\hline 8 & $\mathrm{Hu} \mathrm{B}{ }^{22}$ & NA & Union Hospital & $\begin{array}{l}2020 / 1 / 16- \\
2020 / 2 / 19\end{array}$ & NA & $\begin{array}{c}\text { case } \\
\text { control }\end{array}$ & $\begin{array}{c}214 \\
(127 / 87)\end{array}$ & $\begin{array}{l}\text { laboratory- } \\
\text { confirmed }\end{array}$ & $\begin{array}{c}52.7 \\
(37.2-68.2)\end{array}$ & severity status & 8 \\
\hline 9 & $\underset{15}{\text { Zhang YX }}$ & Clin Infect Dis & Zhongnan Hospital & $\begin{array}{l}2020 / 1 / 1- \\
2020 / 2 / 5\end{array}$ & NA & $\begin{array}{c}\text { case } \\
\text { control }\end{array}$ & $\begin{array}{c}155 \\
(86 / 69)\end{array}$ & $\begin{array}{l}\text { laboratory- } \\
\text { confirmed }\end{array}$ & $54(42-66)$ & severity status & 8 \\
\hline 10 & $\mathrm{Li} \mathrm{LJ}^{36}$ & BMJ & Zhejiang Province & $\begin{array}{l}2020 / 1 / 10- \\
2020 / 1 / 26\end{array}$ & $2020 / 1 / 26$ & $\begin{array}{c}\text { case } \\
\text { control }\end{array}$ & $62(36 / 27)$ & $\begin{array}{l}\text { laboratory- } \\
\text { confirmed }\end{array}$ & $41(32-52)$ & severity status & 8 \\
\hline 11 & Shang $\mathrm{Y}^{12}$ & $\begin{array}{c}\text { The Lancet } \\
\text { Respiratory } \\
\text { Medicine }\end{array}$ & Jinyintan Hospital & $\begin{array}{l}2019 / 12- \\
2020 / 1 / 26\end{array}$ & $2020 / 2 / 9$ & $\begin{array}{c}\text { case } \\
\text { control }\end{array}$ & $52(35 / 17)$ & $\begin{array}{l}\text { laboratory- } \\
\text { confirmed }\end{array}$ & $\begin{array}{c}59.7 \\
(46.4-73.0)\end{array}$ & composite endpoint & 8 \\
\hline 12 & $\underset{16}{\text { Ong, K H }}$ & Am J Hematol & Singapore & $\begin{array}{l}2020 / 1 / 23- \\
2020 / 2 / 28\end{array}$ & $2020 / 2 / 28$ & $\begin{array}{c}\text { case } \\
\text { control }\end{array}$ & $67(37 / 30)$ & $\begin{array}{l}\text { laboratory- } \\
\text { confirmed }\end{array}$ & $42(35-54)$ & composite endpoint & 8 \\
\hline 13 & Wang $\mathrm{Q}^{18}$ & $\begin{array}{l}\text { Journal of } \\
\text { medical } \\
\text { virology }\end{array}$ & $\begin{array}{l}\text { Huizhou municipal central } \\
\text { hospital from }\end{array}$ & $\begin{array}{l}2020 / 1- \\
2020 / 2\end{array}$ & $2020 / 2 / 21$ & $\begin{array}{c}\text { case } \\
\text { control }\end{array}$ & $30(16 / 14)$ & $\begin{array}{l}\text { laboratory- } \\
\text { confirmed }\end{array}$ & $50.5(36-65)$ & severity status & 8 \\
\hline 14 & $\mathrm{Hu} \mathrm{Y}{ }^{27}$ & Chin Med J & Tongji Hospital & $\begin{array}{l}2019 / 12 / 30- \\
2020 / 1 / 15\end{array}$ & $\begin{array}{l}2019 / 12 / 30- \\
2020 / 1 / 15\end{array}$ & $\begin{array}{l}\text { - case } \\
\text { control }\end{array}$ & $78(39 / 39)$ & $\begin{array}{l}\text { laboratory- } \\
\text { confirmed }\end{array}$ & $38(33-57)$ & severity status & 8 \\
\hline 15 & $\begin{array}{c}\text { Chen XM } \\
17\end{array}$ & QJM & Zhejiang province & $\begin{array}{l}2020 / 1 / 20- \\
2020 / 2 / 11\end{array}$ & $2020 / 2 / 16$ & $\begin{array}{c}\text { case } \\
\text { control }\end{array}$ & $91(37 / 54)$ & $\begin{array}{c}88 \\
\text { laboratory- } \\
\text { confirmed } \\
\& 3 \\
\text { clinical- } \\
\text { confirmed }\end{array}$ & $50(36.5-57)$ & severity status & 8 \\
\hline 16 & Gao YD ${ }^{20}$ & Allergy & No. 7 Hospital of Wuhan & $\begin{array}{l}2020 / 1 / 16- \\
2020 / 2 / 3\end{array}$ & NA & $\begin{array}{c}\text { case } \\
\text { control }\end{array}$ & $\begin{array}{c}140 \\
(71 / 69)\end{array}$ & $\begin{array}{l}\text { laboratory- } \\
\text { confirmed }\end{array}$ & $57(25-87)$ & severity status & 8 \\
\hline 17 & $\underset{7}{\text { Zhang RG }}$ & Clin Infect Dis & Union Hospital & $\begin{array}{l}2020 / 1 / 16- \\
2020 / 1 / 29\end{array}$ & $2020 / 2 / 4$ & $\begin{array}{c}\text { case } \\
\text { control }\end{array}$ & $69(32 / 37)$ & $\begin{array}{l}\text { laboratory- } \\
\text { confirmed }\end{array}$ & $\begin{array}{c}42.0 \\
(35.0-62.0)\end{array}$ & severity status & 8 \\
\hline 18 & Zhu CL ${ }^{19}$ & $\begin{array}{c}\text { Clinical } \\
\text { chemistry and } \\
\text { laboratory } \\
\text { medicine }\end{array}$ & Renmin Hospital & $\begin{array}{l}2020 / 1 / 31- \\
2020 / 2 / 10\end{array}$ & NA & $\begin{array}{c}\text { case } \\
\text { control }\end{array}$ & $\begin{array}{c}134 \\
(76 / 68)\end{array}$ & $\begin{array}{l}\text { laboratory- } \\
\text { confirmed }\end{array}$ & NA & severity status & 9 \\
\hline 19 & $\underset{23}{\text { Wang LD }}$ & $\begin{array}{l}\text { Journal of } \\
\text { medical } \\
\text { virology }\end{array}$ & $\begin{array}{c}\text { Fuyang Second people's } \\
\text { hospital }\end{array}$ & $\begin{array}{c}2020 / 1 / 23- \\
20202 / 2\end{array}$ & NA & $\begin{array}{c}\text { case } \\
\text { control }\end{array}$ & $43(26 / 17)$ & $\begin{array}{l}\text { laboratory- } \\
\text { confirmed }\end{array}$ & $43.74 \pm 12.12$ & severity status & 8 \\
\hline 20 & Zeng QT ${ }^{24}$ & $\begin{array}{l}\text { Zhonghua xin } \\
\text { xue guan bing } \\
\text { za zhi }\end{array}$ & Union Hospital & $\begin{array}{l}2020 / 1 / 20- \\
2020 / 2 / 15\end{array}$ & NA & $\begin{array}{c}\text { case } \\
\text { control }\end{array}$ & $\begin{array}{c}112 \\
(53 / 59)\end{array}$ & NA & $62(55-67)$ & severity status & 8 \\
\hline
\end{tabular}




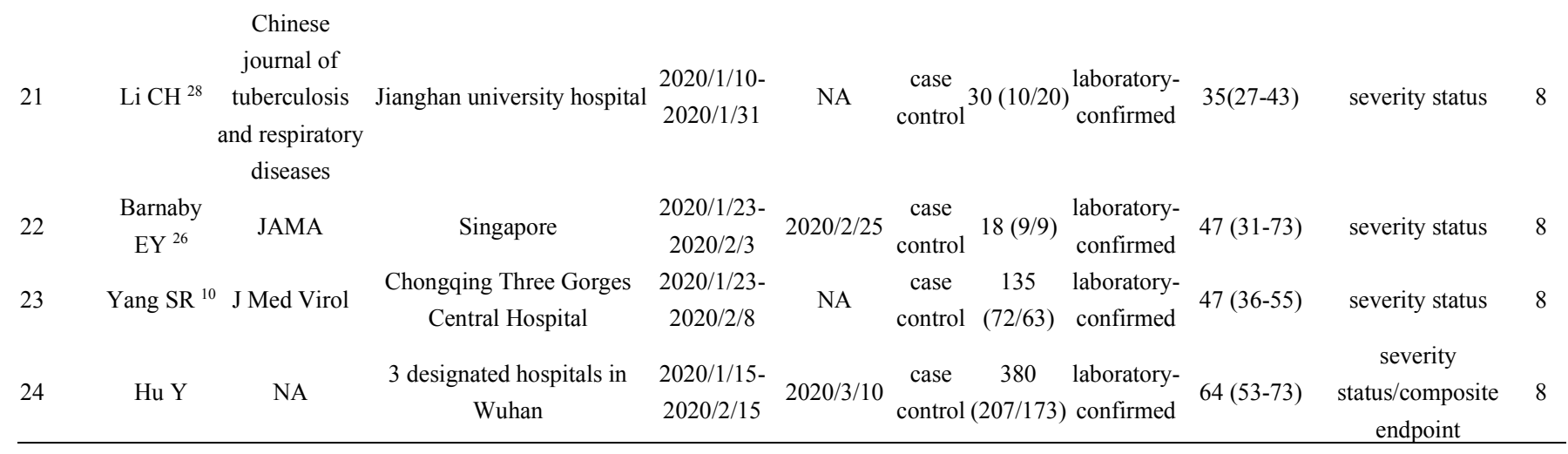

The second column is the corresponding author of the article. Composite endpoint means ICU or death. Not applicable (NA); $\mathrm{M} / \mathrm{F}$ (male/female); Newcastle-Ottawa quality assessment scale (NOS).

Table 2. Summary of the meta-analysis results.

\begin{tabular}{|c|c|c|c|c|c|c|c|c|c|c|c|c|}
\hline Biomarker & $\begin{array}{l}\text { Total no. } \\
\text { of studies }\end{array}$ & $\begin{array}{l}\text { Total no. } \\
\text { of patients }\end{array}$ & Endpoint & $\begin{array}{l}\text { No. of } \\
\text { studies }\end{array}$ & $\begin{array}{c}\text { No. of } \\
\text { patients }\end{array}$ & $\begin{array}{c}\text { Statistical } \\
\text { method }\end{array}$ & $\begin{array}{l}\text { pooled Standard } \\
\text { Mean Difference } \\
\text { (SMD) }\end{array}$ & $\mathbf{P}$ & $\mathbf{I}^{2}$ & $\begin{array}{c}\text { P } \\
\text { (Heterogeneity) }\end{array}$ & $\begin{array}{c}\text { P Begg's } \\
\text { Test }\end{array}$ & $\begin{array}{c}P \\
\text { Egger's } \\
\text { test } \\
\end{array}$ \\
\hline \multirow{2}{*}{ Platelet } & \multirow{2}{*}{16} & \multirow{2}{*}{2980} & $\begin{array}{l}\text { severity } \\
\text { status }\end{array}$ & 12 & 2152 & $\begin{array}{c}\text { I-V, } \\
\text { Random }\end{array}$ & $\begin{array}{c}-0.271 \\
(-0.547-0.005)\end{array}$ & 0.054 & $84.60 \%$ & $<0.001$ & 0.732 & 0.951 \\
\hline & & & $\begin{array}{c}\text { composite } \\
\text { endpoint }\end{array}$ & 6 & 1778 & $\begin{array}{c}\text { I-V, } \\
\text { Random }\end{array}$ & $\begin{array}{c}-0.541 \\
(-1.109-0.028)\end{array}$ & 0.062 & $92.50 \%$ & $<0.001$ & 0.462 & 0.413 \\
\hline \multirow{2}{*}{ PT } & \multirow{2}{*}{11} & \multirow{2}{*}{1641} & $\begin{array}{l}\text { severity } \\
\text { status }\end{array}$ & 7 & 940 & $\begin{array}{c}\mathrm{I}-\mathrm{V}, \\
\text { Random }\end{array}$ & $\begin{array}{c}0.803 \\
(0.254-1.352)\end{array}$ & 0.004 & $91.30 \%$ & $<0.001$ & 0.368 & 0.224 \\
\hline & & & $\begin{array}{l}\text { composite } \\
\text { endpoint }\end{array}$ & 5 & 645 & $\begin{array}{c}\mathrm{I}-\mathrm{V}, \\
\text { Random }\end{array}$ & $\begin{array}{c}1.338 \\
(0.551-2.125)\end{array}$ & 0.001 & $92.70 \%$ & $<0.001$ & 1.000 & 0.300 \\
\hline \multirow{2}{*}{ APTT } & \multirow{2}{*}{10} & \multirow{2}{*}{1388} & $\begin{array}{l}\text { severity } \\
\text { status }\end{array}$ & 7 & 940 & $\begin{array}{c}\mathrm{I}-\mathrm{V}, \\
\text { Random }\end{array}$ & $\begin{array}{c}-0.133 \\
(-0.668-0.402)\end{array}$ & 0.625 & $91.50 \%$ & $<0.001$ & 0.368 & 0.499 \\
\hline & & & $\begin{array}{l}\text { composite } \\
\text { endpoint }\end{array}$ & 4 & 593 & $\begin{array}{c}\text { I-V, } \\
\text { Random }\end{array}$ & $\begin{array}{c}0.327 \\
(-0.630-1.285)\end{array}$ & 0.503 & $94.90 \%$ & $<0.001$ & 0.734 & 0.591 \\
\hline \multirow[b]{2}{*}{ D-dimer } & \multirow[b]{2}{*}{13} & \multirow[b]{2}{*}{1762} & $\begin{array}{l}\text { severity } \\
\text { status }\end{array}$ & 11 & 1438 & $\begin{array}{c}\mathrm{I}-\mathrm{V}, \\
\text { Random }\end{array}$ & $\begin{array}{c}0.787 \\
(0.277-1.298)\end{array}$ & 0.003 & $96.70 \%$ & $<0.001$ & 0.062 & 0.510 \\
\hline & & & $\begin{array}{c}\text { composite } \\
\text { endpoint }\end{array}$ & 3 & 410 & $\begin{array}{c}\text { I-V, } \\
\text { Random }\end{array}$ & $\begin{array}{c}1.523 \\
(-0.221-3.267)\end{array}$ & 0.087 & $97.50 \%$ & $<0.001$ & 1.000 & 0.805 \\
\hline Fibrinogen & 5 & 682 & - & - & - & $\begin{array}{c}\mathrm{I}-\mathrm{V}, \\
\text { Random }\end{array}$ & $\begin{array}{c}0.559 \\
(-0.599-1.718)\end{array}$ & 0.344 & $96.70 \%$ & $<0.001$ & 0.806 & 0.317 \\
\hline FDP & 3 & 548 & - & - & - & $\begin{array}{c}\mathrm{I}-\mathrm{V}, \\
\text { Random }\end{array}$ & $\begin{array}{c}1.046 \\
(0.371-1.722)\end{array}$ & 0.002 & $88.90 \%$ & $<0.001$ & 1.000 & 0.806 \\
\hline Antithrombin & 3 & 548 & - & - & - & $\begin{array}{c}\mathrm{I}-\mathrm{V}, \\
\text { Random }\end{array}$ & $\begin{array}{c}-0.798(-1.217-- \\
0.379) \\
\end{array}$ & $<0.001$ & $72.20 \%$ & 0.027 & 0.296 & 0.190 \\
\hline
\end{tabular}

prothrombin time (PT); activated partial thromboplastin time (APTT); fibrin/fibrinogen degradation products (FDP).

\section{The relationship between APTT and disease severity or composite endpoint}

10 articles with 1388 COVID-19 patients were analyzed for the relationship between disease prognosis and APTT (Table 2); 7 articles with 940 patients were assessed for the relationship between
APTT and disease severity [4, 10, 19, 21, 23, 24], and 593 patients in four articles were studied for the relationship between APTT and composite endpoint $[5,11,13]$. Our results revealed that APTT was not statistically associated with disease severity and composite endpoint at admission (Table 2, Figures 2 and 3$)$. 
The relationship between fibrinogen, fibrin/ fibrinogen degradation products (FDP), antithrombin, and prognosis

Five studies with 682 patients were analyzed for the effect of fibrinogen on prognosis $[11,17,19,23]$. We found that fibrinogen had no value in predicting disease prognosis in COVID-19 patients (SMD 0.559 (-0.5991.718), $P=0.344, I^{2}=96.7 \%$ ) (Supplementary Figure 1). Furthermore, 548 cases in three articles were evaluated for the relationship between FDP, antithrombin, and prognosis [11, 19]. Our results revealed that increased FDP (SMD 1.046 (0.371-1.722, $P=0.002, I^{2}=88.9 \%$ ) and decreased antithrombin (SMD -0.798 (-1.217-0.379), $P<0.001, I^{2}=72.2 \%$ ) were associated with the worsening of COVID-19 (Table 2, Supplementary Figure 2).

\section{Sensitivity analysis and publication bias}

A Funnel plot was drawn to test publication bias, and Egger's test and Begg's test indicated that there was no publication bias (Supplementary Figures 3, 4).
Sensitivity analysis revealed that no study greatly interfered with the results of this meta-analysis study greatly interfered with the results of this meta-analysis, suggesting that the study was stable (Supplementary Figures 5, 6).

\section{DISCUSSION}

COVID-19 has raised great public health concerns globally over the last three months. Like with SARS, abnormal coagulation disorders are common in severe patients with COVID-19. Our meta-analysis combined the outcomes of 3544 COVID-19 patients from 24 separate studies and established that elevated D-dimer significantly predicted more severe classifications of COVID-19 patients. Prolonged PT at baseline also suggested poor outcomes, both in severity status and composite endpoint. Increased FDPs and decreased antithrombin might also signal severe conditions.

The platelet count at admission had no remarkable relationship with outcome. However, a meta-analysis
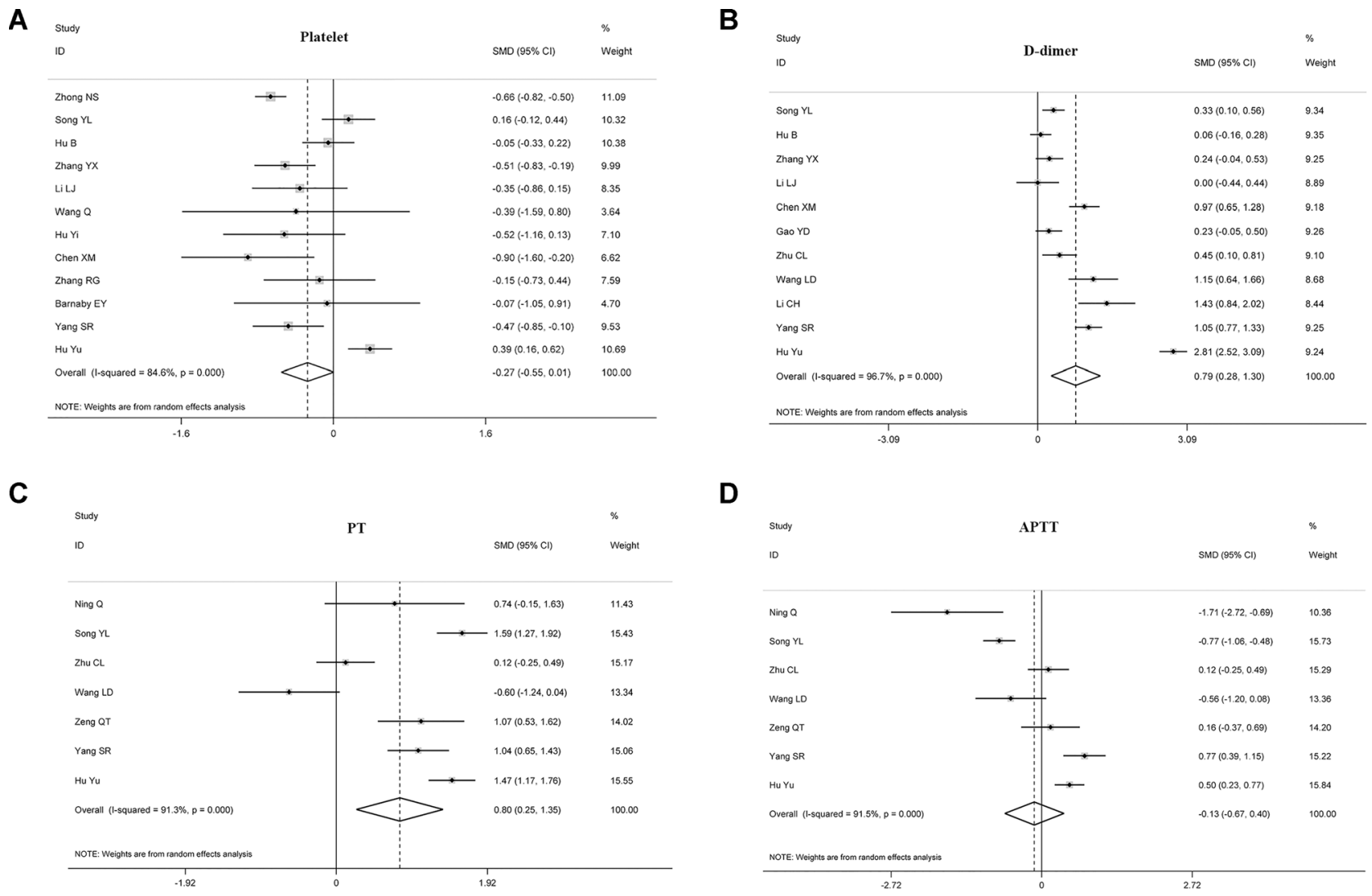

Figure 2. Forest plots assessing the severity status of COVID-19 patients, as determined using coagulation parameters. The sizes of the blocks or diamonds represent the weights, and the lengths of the straight lines represent the widths of the $95 \%$ Cls. (A) comparing patients by platelet counts; (B) comparing patients by D-dimer levels; (C) comparing patients by PT; (D) comparing patients by APTT. prothrombin time (PT); activated partial thromboplastin time (APTT). 
involving 399 subjects showed that platelet counts at admission were significantly lower in more severe and non-survivor COVID-19 patients [29]. This discrepancy in outcome regarding platelet counts may be due to inconsistencies in the selected literature. A national multi-center retrospective study led by Academician Zhong supported the conclusion that platelet count is not statistically linked to a composite endpoint, although the authors also found that severe patients had lower platelets on admission than non-severe patients. One possible reason was the difference in the research objects. In other selected articles, the patients were either in Wuhan or outside Wuhan. The objects in Zhong's article included hospitalized patients both in Wuhan and outside-Wuhan. The early epidemic situation in Wuhan was overwhelming, medical resources were tight, and patients with a milder disease were isolated at home while more severe patients were admitted to the hospital. Patients hospitalized outside-Wuhan got sufficient resources due to they having relatively few cases at the time.

Platelets play a crucial role in hemostasis and thrombosis. While platelet activation and thrombocytosis increase the risk of thrombotic complications, platelet function disorders and thrombocytopenia increase bleeding risk. Thrombocytopenia and reactive thrombocytosis are both common in a variety of viral infections [30-35]. During SARS, most patients' platelet counts were normal at the onset of the disease, but, with time, 55\% developed thrombocytopenia (platelet count $<140 \times 10^{9} / \mathrm{L}$ ), and $49 \%$ harbored reactive thrombocytosis (platelet count $\geq 400 \times 10^{9} / \mathrm{L}$ ) [32]. Similarly, in COVID-19 patients, platelet counts were also within the normal range in most cases at admission $[4,7,13,15,16,26,36]$; thrombocytopenia (platelet count $<100 \times 10^{9} / \mathrm{L}$ ) was reported primarily in severe patients or non-survivors $(20 \% \sim 66.1 \%)[5,8$, 11], while thrombocytosis was reported in a few articles, and the proportion was not assessed [21]. The outcome of platelet count changes for the entirety of COVID-19 infection in patients has rarely been reported. Until recently, according to the article with 1476 COVID-19 patients by Yang et al., platelet counts in survivors tended to be stable during hospitalization, but they progressively decreased in non-survivors [37]. Furthermore, the lower the nadir platelet count during hospitalization, the higher the risk of death [37].

\section{A}

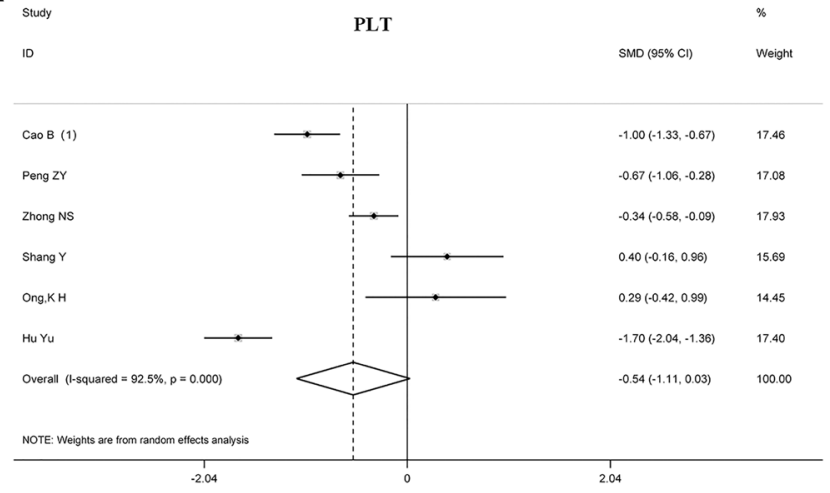

C

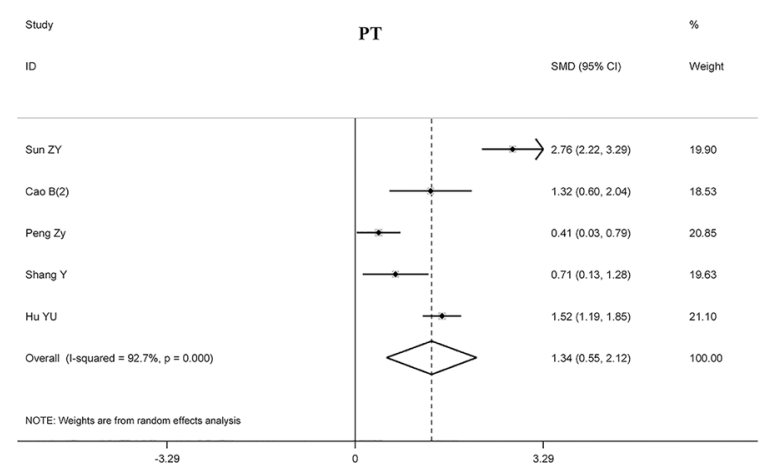

B

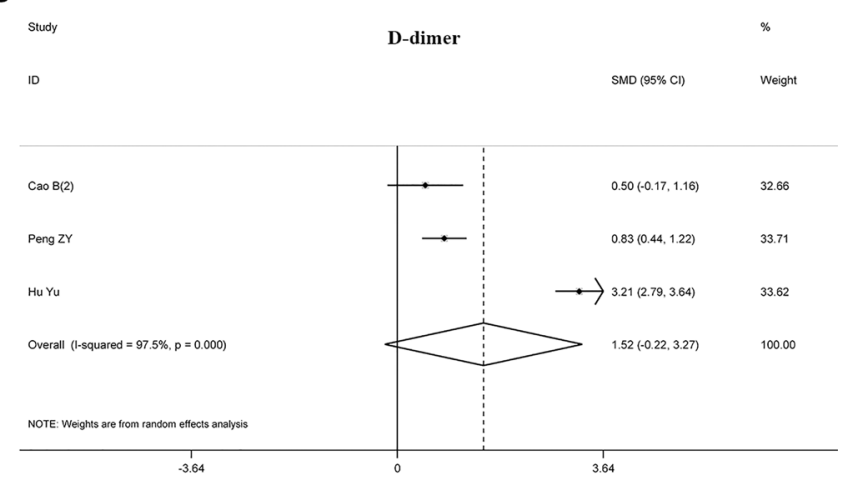

D

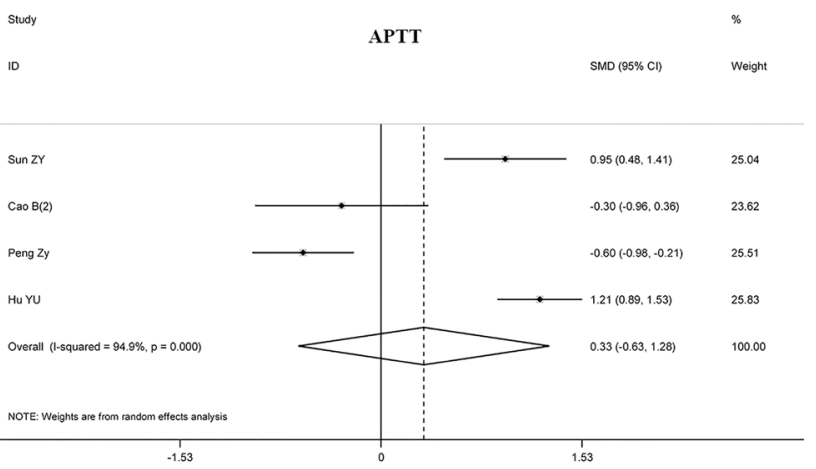

Figure 3. Forest plots assessing the composite endpoint of COVID-19 patients, as determined using coagulation parameters. The sizes of the blocks or diamonds represent the weights, and the lengths of the straight lines represent the widths of the 95\% Cls. (A) Comparing patients by platelet counts; (B) comparing patients by D-dimer levels; (C) comparing patients by PT; (D) comparing patients by APTT. prothrombin time (PT); activated partial thromboplastin time (APTT). 
Thrombocytopenia is often considered an indicator of bleeding and mortality in critical patients [38]. Decreased platelet counts help recognize the presence and severity of coagulopathy [39]. The mechanisms of thrombocytopenia during COVID-19 might include direct or indirect factors induced by the SARS-Cov2 infection, such as inappropriate platelet activation and consumption, immunological platelet destruction, and impaired megakaryopoiesis [40]. Recently, Levi M et al. proposed that localized pulmonary thrombotic microangiopathy where platelet consumption is a common feature, may partly account for thrombocytopenia [41]. Additionally, two independent teams found that COVID-19 patients in ICU had markedly elevated levels of the von Willebrand factor [42, 43], further supporting Levi M's opinion. Though COVID19-associated coagulopathy belongs to sepsis-induced coagulopathy, thrombocytopenia is less profound [43], which may be related with that COVID-19-accociatedcoagulopathy was a severe hypercoagulability rather than consumptive coagulopathy [44]. Bleeding events are less documented or reported in current articles looking at the clinical features of COVID-19, although autopsies have revealed focal hemorrhage in the lungs and spleen and decreased myelopoiesis in the bone marrow [45]. Mao's team found that one of 88 severe patients had a cerebral hemorrhage [21]. Yang et al. showed that $6 \%$ of 32 non-survivors had a gastrointestinal hemorrhage [12]. In addition to low platelets, bleeding events in critical COVID-19 patients may also be linked to corticosteroid therapy in more critically ill patients. In the interim guidance of coagulopathy in COVID-19, the ISTH recommends that platelet counts be kept above $50 \times 10^{9} / \mathrm{L}$ in bleeding patients and above $20 \times 10^{9} / \mathrm{L}$ in non-bleeding patients.

D-dimer, a more specific marker than FDP reflecting the dissolution of microthrombi, is amplified in septic patients [46], consistent with what is reported in COVID-19 patients $[6,10,11,20,22,23]$. In nonCOVID-19 septic patients, D-dimer concentrations do not reach the high values seen in patients with COVID19 [41, 43]. Generally, FDP correlates positively well with D-dimer, except in some situations, like primary hyperfibrinolysis, and simultaneous measurements of FDPs and D-dimer are useful for more accurate estimations of fibrinolytic states [47]. However, of the articles that met our inclusion criteria, only three provided FDP information, whereas, many articles recorded D-dimer changes. Strikingly, $43.2 \% \sim 68 \%$ of COVID-19 patients had elevated levels of D-dimer [5, $8,20]$, and this proportion was as high as $92 \%$ in dead patients [5]. Increased D-dimer levels generally indicate a high risk of thrombotic diseases [48]. By the time we started this meta-analysis, the incidence of thrombosis had rarely been reported in COVID-19 patients, although thrombosis and microthrombosis in multiple organs had been observed during autopsies [45]. In a study specifically looking at neurological manifestations, Mao and colleagues revealed that $4.5 \%$ of severe COVID-19 patients had an acute ischemic stroke [22]. Another study found that $3.4 \%$ of severe COVID-19 patients had a stroke [20]. Recently, several teams in different countries emphasized the high incidence of thrombotic events in severe COVID-19 patients. In a study of 81 ICU patients without routine thromboprophylaxis in China, the incidence of deep vein thrombosis was $25 \%$ [49]. In Netherlands, two independent researches where routine low molecular weight heparin prophylaxis was applied, reported similar (even higher) incidence of venous thromboembolism (VTE) among ICU patients with COVID-19 $[50,51]$. Most recently, Helms et al. showed that COVID-19-ARDS patients developed significantly more thrombotic complications than non-COVID-19ARDS patients based on a multicenter prospective cohort study [43].

In COVID-19 patients, especially severe patients, the mechanisms of elevated D-dimer or thrombosis may include older age, chronic diseases, hypoxemia, hypercytokinemia, coagulopathy, and inevitable prolonged bed rest. It is already well-established that older individuals and those who have co-morbidities and hypercytokinemia are more likely to die from COVID19 infection [4, 5, 7, 8, 11, 20, 21, 23, 24]. Aging and chronic diseases are recognized risk factors for sepsis, which is characterized by excessive inflammation, including hypercytokinemia and endothelial dysfunction, resulting in a hypercoagulability state $[42,52]$. Refractory hypoxemia may lead to vasoconstriction reducing blood flow and promoting vascular occlusion [53]. SARS- and COVID-19-associated coagulopathy is sepsis-induced, generally characterized by markedly increased levels of plasminogen activator inhibitor-1 (PAI-1) [46, 54]. Consistently, the PAI-1 level in SARS patients is significantly higher, not only compared to healthy controls but also patients with other cases of pneumonia [55], and whether this is so in COVID-19 patients is a matter still to be verified.

Generally, coagulation tests are prolonged when the level of coagulation factors is below $50 \%$, and an abnormality may occur up to the decompensation period of DIC because of the consumption of clotting factors during DIC progression $[46,56]$. However, at the early stage of septic DIC, coagulation tests may be shortened because of hypercoagulability. This meta-analysis showed that PT, but not APTT, had an increased risk of ICU and death on admission, perhaps because coagulopathy in COVID-19 is sepsis-induced, where mostly the exogenous, but not the endogenous, 
coagulation pathway is activated. Given that PT and APTT are within the reference ranges on admission in most COVID-19 patients, baseline PT and APTT have limited values for risk stratification and prognosis in COVID-19 patients [5, 13, 19]. However, PT can progressively extend in nonsurvivors [11], due to the continuous activation and consumption of the exogenous coagulation pathway. As an acute reactive protein, hyperfibrinogenemia is common in the early phase of COVID-19 in both survivors and nonsurvivors [11]. Yet, the level of fibrinogen can progressively decrease in non-survivors, and hypofibrinogenemia may be observed at the late stage of consumption coagulopathy [11]. Antithrombin may be readily exhausted during continuous thrombin generation, with low levels of antithrombin found in approximately $50 \%$ of critically ill patients and $90 \%$ of DIC patients [56]. Therefore, the dynamic monitoring of these coagulation tests is highly recommended.

The combination of thrombocytopenia, increased Ddimer, prolonged PT, and decreased antithrombin is suggestive of DIC, though the majority of COVID-19 patients would not meet the Overt-DIC criteria established by the International Society on Thrombosis and Hemostasis (ISTH) [41, 43]. The ISTH positively recommends anticoagulants when septic patients meet the diagnostic criteria of sepsis-induced coagulopathy (SIC) [54], which could result in a significant reduction in mortality [57, 58]. However, patients with advanced coagulopathy may have a disease progression that is no longer amenable to anticoagulant therapy [59]. For that reason, the ISTH recommends a two-step diagnosis for sepsis-associated coagulopathy and emphasizes that therapeutic doses of heparin should be considered in coagulopathic patients to avoid progression from coagulopathy to DIC [54]. Increasing evidence demonstrates that there is a high risk of thrombotic complications in severe COVID-19 patients, and early anticoagulation therapy seems to improve the outcome of severe COVID-19 patients [43, 49-51, 60-62]. Tang's team specifically looking at anticoagulant treatments showed that the 28-day mortality rate of COVID-19 patients using heparin was lower than that of nonusers in cases of severe COVID-19 patients meeting SIC criteria or with D-dimer $>3.0 \mathrm{ug} / \mathrm{mL}$ [60]. Llitjos et al. revealed that, among the twenty-six COVID-19 patients with mechanical ventilation, the incidence of VTE in patients treated with prophylactic anticoagulation was significantly higher than that in the group receiving therapeutic anticoagulation [63]. In a prospective observational study with sixteen ICU COVID-19 patients, Ranucci et al. showed that the pro-coagulant situation of patients gradually improved after thromboprophylaxis was increased [64]. Zhang et al. revealed that the thromboprophylaxis halved the incidence of DVT in
COVID-19 patients with a Padua prediction score $\geq 4$ [65]. Given that COVID-19-ARDS patients had higher risk of thrombotic complications than non-COVID-19-ARDS patients, Helms et al. suggested the presence of higher anticoagulation targets in critically ill patients than usual [43]. However, the efficacy of anticoagulant therapy needs to be verified in high-quality RCT experiments. Clinicians should closely monitor indicators during the laboratory examination of patients to stay alert for side effects after anticoagulant treatment [66].

Our study has several limitations. First, all the studies included in this meta-analysis are retrospective studies with large heterogeneity. Second, the data came mainly from China; factors such as virus strain types, medical levels, countries, races, etc., may affect the results. However, at the moment, more detailed subgroup analyses cannot be conducted to comprehensively understand COVID-19 because the material for this is limited. Third, for some parameters, the number of studies included in the meta-analysis was less than 10 . In this case, the publication bias may, therefore, not have been detected by Egger's and Begg's tests because of the relatively lower power. Fourth, the pooled sample sizes were not large enough. Precise estimates of these parameters should be assessed further.

\section{CONCLUSIONS}

Elevated D-dimer and FDP, prolonged PT, and decreased antithrombin predict higher risk stratification and poorer prognosis in COVID-19, which is perhaps not fully in line with the facts because the studies selected for the meta-analysis were limited. There is, however, no doubt that early coagulation tests and dynamically monitoring coagulation indicators during hospitalization are helpful in the early identification of coagulation disorders, and the rational use of these parameters and the scoring systems help guide treatment and improve the prognosis of COVID-19.

\section{MATERIALS AND METHODS}

\section{Search strategy}

We conducted this systematic review and meta-analysis using a predefined protocol under PRISMA guidelines [67]. We searched PubMed, Web of Science, Cochrane Library, and Scopus electronically. Medical subject headings and random words (e.g. COVID-19) were combined to search the databases without language or ethnic origin restriction and dated up to March 24, 2020 (for detailed search methods, see Supplementary Table 2). The titles, abstracts, and full texts of all documents were identified independently by two investigators, and disagreements were adjudicated by a third investigator. 
The reference list of all identified documents was scrutinized to identify additional potentially eligible studies.

\section{Inclusion and exclusion}

The criteria for including a study in the meta-analysis were as follows: (I) the COVID-19 patient cohort was confirmed primarily by laboratory detection; (II) the endpoint was severity status and/or composite endpoint (including ICU monitoring and death); (III) groups were established for comparison; (IV) the correlation of coagulation biomarkers with endpoints was recorded. Exclusion criteria were as follows: (I) review articles, case reports, and laboratory studies; (II) studies with insufficient data for estimating pooled standard mean differences (SMD).

\section{Data extraction}

We collected the following items from each study, if available: the corresponding author's name, the study type, the institute or region, the period of case collection and follow-up, the number of reported cases, disease severity, complications (e.g., coagulopathy and DIC), outcome, and laboratory findings (e.g., platelet, Ddimer, PT, APTT, or fibrinogen) were entered in a welldesigned form independently by two investigators. If different articles published by the same institution overlapped during case inclusion, the research with the largest number of cases was selected, and the others were excluded. A third investigator checked the article list and data extraction to ensure that there were no duplicate articles or duplicate information and made a judgment on controversial articles.

\section{Quality assessment}

Two reviewers independently evaluated the methodological quality of each selected study. The quality of case-control studies was evaluated using the NewcastleOttawa quality assessment scale (NOS) [68], which comprises 9 points; 4 points for selection, 2 points for comparability, and 3 points for the outcome. Six or more points in case-control studies were regarded as high quality. Disagreements were resolved by discussion.

\section{Statistical analysis}

Version 12.0 of the STATA statistical software (STATA, College Station, TX) was used to calculate the combined survival impact of indicators of coagulation. The impact of biomarkers on endpoints was determined by calculating pooled mean values and their $95 \%$ CIs. Results suggested statistical significance if the $95 \%$ CI was no more than 0. Also, increased indicator levels contributed to an adverse survival effect, compared to control-patients, when the pooled mean value was more than 0 . The heterogeneity of the selected studies was evaluated using the chi-squared test, with significance set at a p-value of less than 0.10 . The statistic $\mathrm{I}^{2}$ was used to quantify heterogeneity; an $\mathrm{I}^{2}$ value less than $25 \%$ was regarded as low heterogeneity, a value between 25 and $50 \%$ indicated moderate heterogeneity, and a value over 50\% signaled high heterogeneity [69]. The random-effect model was used if high heterogeneity was observed; otherwise, a fixed-effect model was used for the meta-analysis. Sensitivity analysis was applied to explore the origin of heterogeneity. Funnel plots, Begg's test, and Egger's test were used to screen for potential publication bias of the total population. Poor stability resulting from the inclusion and exclusion of studies was reappraised.

\section{Abbreviations}

COVID-19: Coronavirus Disease 2019; SARS-Cov-2: severe acute respiratory syndrome coronavirus 2; ARDS: acute respiratory distress syndrome; MERS-CoV: Middle East Respiratory Syndrome coronavirus; DIC: disseminated intravascular coagulation; PT: prothrombin time; APTT: activated partial thromboplastin time; FDP: fibrin/fibrinogen degradation products; SMD: standard mean differences; VTE: venous thromboembolism. NOS:Newcastle-Ottawa quality assessment scale.

\section{AUTHOR CONTRIBUTIONS}

MH and HY conceived and designed the study. LLL, XM, DMY, KHM, LDY and CZP contributed to the literature searches, study selection, data extraction, quality assessment, data analysis and interpretation. LLL, $\mathrm{XM}$ and DMY drafted the initial manuscript, and $\mathrm{MH}$ and HY made critical revisions to the intellectual content. All authors approved the final version of the study.

\section{CONFLICTS OF INTEREST}

The authors declare that they have no conflicts of interest

\section{FUNDING}

This study was supported by grant from the Key Special Project of Ministry of Science and Technology, China (No.2020YFC0845700), the Fundamental Research Funds for the Central Universities (NO. 2020kfyXGY J029), and the Emergency Fund of Huazhong University of Science and Technology for 2020 New Coronavirus Pneumonia. 


\section{REFERENCES}

1. Zhu N, Zhang D, Wang W, Li X, Yang B, Song J, Zhao X, Huang B, Shi W, Lu R, Niu P, Zhan F, Ma X, et al. A Novel Coronavirus from Patients with Pneumonia in China, 2019. N Engl J Med. 2020; 382:727-733.

https://doi.org/10.1056/NEJMoa2001017 PMID:31978945

2. Yang S, Wu J, Ding C, Cui Y, Zhou Y, Li Y, Deng M, Wang C, Xu K, Ren J, Ruan B, Li L. Epidemiological features of and changes in incidence of infectious diseases in China in the first decade after the SARS outbreak: an observational trend study. Lancet Infect Dis. 2017; 17:716-25.

https://doi.org/10.1016/S1473-3099(17)30227-X PMID:28412150

3. Chen J. Pathogenicity and transmissibility of 2019nCoV-a quick overview and comparison with other emerging viruses. Microbes Infect. 2020; 22:69-71. https://doi.org/10.1016/i.micinf.2020.01.004 PMID:32032682

4. Wu C, Chen X, Cai Y, Xia J, Zhou X, Xu S, Huang H, Zhang L, Zhou X, Du C, Zhang Y, Song J, Wang S, et al. Risk factors associated with acute respiratory distress syndrome and death in patients with coronavirus disease 2019 pneumonia in Wuhan, China. JAMA Intern Med. 2020; 180:934.

https://doi.org/10.1001/jamainternmed.2020.0994 PMID:32167524

5. Zhou F, Yu T, Du R, Fan G, Liu Y, Liu Z, Xiang J, Wang Y, Song B, Gu X, Guan L, Wei Y, Li H, et al. Clinical course and risk factors for mortality of adult inpatients with COVID-19 in Wuhan, China: a retrospective cohort study. Lancet. 2020; 395:1054-62.

https://doi.org/10.1016/S0140-6736(20)30566-3 PMID:32171076

6. Huang C, Wang Y, Li X, Ren L, Zhao J, Hu Y, Zhang L, Fan G, Xu J, Gu X, Cheng Z, Yu T, Xia J, et al. Clinical features of patients infected with 2019 novel coronavirus in Wuhan, China. Lancet. 2020; 395:497-506. https://doi.org/10.1016/S0140-6736(20)30183-5 PMID:31986264

7. Wang Z, Yang B, Li Q, Wen L, Zhang R. Clinical features of 69 cases with coronavirus disease 2019 in Wuhan, China. Clin Infect Dis. 2020. [Epub ahead of print]. https://doi.org/10.1093/cid/ciaa272 PMID:32176772

8. Guan WJ, Ni ZY, Hu Y, Liang WH, Ou CQ, He JX, Liu L, Shan H, Lei CL, Hui DS, Du B, Li LJ, Zeng G, et al, and China Medical Treatment Expert Group for Covid-19. Clinical Characteristics of Coronavirus Disease 2019 in China. N Engl J Med. 2020; 382:1708-20. https://doi.org/10.1056/NEJMoa2002032 PMID: $\underline{32109013}$
9. Chen N, Zhou M, Dong X, Qu J, Gong F, Han Y, Qiu Y, Wang J, Liu Y, Wei Y, Xia J, Yu T, Zhang X, Zhang L. Epidemiological and clinical characteristics of 99 cases of 2019 novel coronavirus pneumonia in Wuhan, China: a descriptive study. Lancet. 2020; 395:507-13.

https://doi.org/10.1016/S0140-6736(20)30211-7 PMID:32007143

10. Wan S, Xiang Y, Fang W, Zheng Y, Li B, Hu Y, Lang C, Huang $D$, Sun $Q$, Xiong $Y$, Huang $X$, Lv J, Luo $Y$, et al. Clinical features and treatment of COVID-19 patients in northeast Chongqing. J Med Virol. 2020; 92:797-806. https://doi.org/10.1002/jmv.25783 PMID: $\underline{32198776}$

11. Tang N, Li D, Wang X, Sun Z. Abnormal coagulation parameters are associated with poor prognosis in patients with novel coronavirus pneumonia. J Thromb Haemost. 2020; 18:844-847.

https://doi.org/10.1111/ith.14768

PMID:32073213

12. Yang $X$, Yu Y, Xu J, Shu H, Xia J, Liu H, Wu Y, Zhang L, Yu $Z$, Fang $M, Y u T$, Wang $Y$, Pan $S$, et al. Clinical course and outcomes of critically ill patients with SARS-CoV-2 pneumonia in Wuhan, China: a single-centered, retrospective, observational study. Lancet Respir Med. 2020; 8:475-481.

https://doi.org/10.1016/S2213-2600(20)30079-5 PMID:32105632

13. Wang D, Hu B, Hu C, Zhu F, Liu X, Zhang J, Wang B, Xiang $\mathrm{H}$, Cheng Z, Xiong $\mathrm{Y}$, Zhao $\mathrm{Y}$, Li Y, Wang X, Peng Z. Clinical characteristics of 138 hospitalized patients with 2019 novel coronavirus-infected pneumonia in Wuhan, China. JAMA. 2020; 323:1061-69.

https://doi.org/10.1001/jama.2020.1585 PMID: $\underline{32031570}$

14. Ralph AG, Brainard BM. Update on disseminated intravascular coagulation: when to consider it, when to expect it, when to treat it. Top Companion Anim Med. 2012; 27:65-72.

https://doi.org/10.1053/j.tcam.2012.06.004 PMID:23031458

15. Mo $P$, Xing $Y$, Xiao $Y$, Deng $L$, Zhao $Q$, Wang $H$, Xiong $Y$, Cheng Z, Gao S, Liang K, Luo M, Chen T, Song S, et al. Clinical characteristics of refractory COVID-19 pneumonia in Wuhan, China. Clin Infect Dis. 2020. [Epub ahead of print]. https://doi.org/10.1093/cid/ciaa270 PMID: $\underline{32173725}$

16. Fan BE, Chong VC, Chan SS, Lim GH, Lim KG, Tan GB, Mucheli SS, Kuperan P, Ong KH. Hematologic parameters in patients with COVID-19 infection. Am J Hematol. 2020; 95:E131-34.

https://doi.org/10.1002/ajh.25774 PMID: $\underline{32129508}$ 
17. Qian GQ, Yang NB, Ding F, Ma AH, Wang ZY, Shen YF, Shi CW, Lian X, Chu JG, Chen L, Wang ZY, Ren DW, Li GX, et al. Epidemiologic and clinical characteristics of 91 hospitalized patients with COVID-19 in Zhejiang, China: a retrospective, multi-centre case series. QJM. 2020. 113:474-81

https://doi.org/10.1093/qjmed/hcaa089

PMID: 32181807

18. Qu R, Ling Y, Zhang YH, Wei LY, Chen X, Li XM, Liu XY, Liu HM, Guo Z, Ren H, Wang Q. Platelet-to-lymphocyte ratio is associated with prognosis in patients with coronavirus disease-19. J Med Virol. 2020; 10:1002.

https://doi.org/10.1002/jmv.25767 PMID:32181903

19. Han H, Yang L, Liu R, Liu F, Wu KL, Li J, Liu XH, Zhu CL. Prominent changes in blood coagulation of patients with SARS-CoV-2 infection. Clin Chem Lab Med. 2020; 58:1116-20.

https://doi.org/10.1515/cclm-2020-0188

PMID:32172226

20. Zhang JJ, Dong X, Cao YY, Yuan YD, Yang YB, Yan YQ, Akdis CA, Gao YD. Clinical characteristics of 140 patients infected with SARS-CoV-2 in Wuhan, China. Allergy. 2020. 75:1730-41.

https://doi.org/10.1111/all.14238

PMID:32077115

21. Chen G, Wu D, Guo W, Cao Y, Huang D, Wang $H$, Wang $\mathrm{T}$, Zhang $\mathrm{X}$, Chen $\mathrm{H}, \mathrm{Yu} \mathrm{H}$, Zhang $\mathrm{X}$, Zhang $\mathrm{M}$, Wu S, et al. Clinical and immunological features of severe and moderate coronavirus disease 2019. J Clin Invest. 2020; 130:2620-29.

https://doi.org/10.1172/JCl137244

PMID:32217835

22. Mao L, Jin H, Wang M, Hu Y, Chen $S$, He Q, Chang J, Hong C, Zhou Y, Wang D, Miao X, Li Y, Hu B. Neurologic Manifestations of Hospitalized Patients With Coronavirus Disease 2019 in Wuhan, China. JAMA Neurol. 2020; 77:1-9. [Epub ahead of print]. https://doi.org/10.1001/jamaneurol.2020.1127 PMID:32275288

23. Gao Y, Li T, Han M, Li X, Wu D, Xu Y, Zhu Y, Liu Y, Wang $X$, Wang L. Diagnostic utility of clinical laboratory data determinations for patients with the severe COVID-19. J Med Virol. 2020; 92:791-96.

https://doi.org/10.1002/jmv.25770

PMID:32181911

24. Peng YD, Meng K, Guan HQ, Leng L, Zhu RR, Wang BY, He MA, Cheng LX, Huang K, Zeng QT. [Clinical characteristics and outcomes of 112 cardiovascular disease patients infected by 2019-nCoV]. Zhonghua Xin Xue Guan Bing Za Zhi. 2020; 48:450-55.

https://doi.org/10.3760/cma.j.cn112148-2020022000105 PMID: $\underline{32120458}$

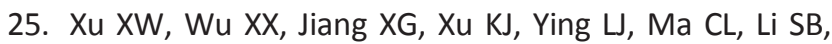
Wang HY, Zhang S, Gao HN, Sheng JF, Cai HL, Qiu YQ, Li $\amalg$. Clinical findings in a group of patients infected with the 2019 novel coronavirus (SARS-Cov-2) outside of Wuhan, China: retrospective case series. BMJ. 2020; 368:m606. https://doi.org/10.1136/bmj.m606 PMID:32075786

26. Young BE, Ong SW, Kalimuddin S, Low JG, Tan SY, Loh J, Ng OT, Marimuthu K, Ang LW, Mak TM, Lau SK, Anderson DE, Chan KS, et al, and Singapore 2019 Novel Coronavirus Outbreak Research Team. Epidemiologic features and clinical course of patients infected with SARS-CoV-2 in Singapore. JAMA. 2020; 323:1488-94. https://doi.org/10.1001/jama.2020.3204 PMID:32125362

27. Liu W, Tao ZW, Wang L, Yuan ML, Liu K, Zhou L, Wei S, Deng Y, Liu J, Liu HG, Yang M, Hu Y. Analysis of factors associated with disease outcomes in hospitalized patients with 2019 novel coronavirus disease. Chin Med J (Engl). 2020; 133:1032-38.

https://doi.org/10.1097/CM9.0000000000000775 PMID:32118640

28. Liu M, He P, Liu HG, Wang XJ, Li FJ, Chen S, Lin J, Chen $\mathrm{P}$, Liu JH, Li CH. [Clinical characteristics of 30 medical workers infected with new coronavirus pneumonia]. Zhonghua Jie He He Hu Xi Za Zhi. 2020; 43:209-214. https://doi.org/10.3760/cma.j.issn.10010939.2020.03.014 PMID: $\underline{32164090}$

29. Lippi G, Plebani M, Henry BM. Thrombocytopenia is associated with severe coronavirus disease 2019 (COVID-19) infections: a meta-analysis. Clin Chim Acta. 2020; 506:145-48.

https://doi.org/10.1016/i.cca.2020.03.022 PMID: $\underline{32178975}$

30. Ballem PJ, Belzberg A, Devine DV, Lyster D, Spruston B, Chambers H, Doubroff P, Mikulash K. Kinetic studies of the mechanism of thrombocytopenia in patients with human immunodeficiency virus infection. N Engl J Med. 1992; 327:1779-84.

https://doi.org/10.1056/NEJM199212173272503 PMID:1435932

31. Flaujac C, Boukour S, Cramer-Bordé E. Platelets and viruses: an ambivalent relationship. Cell Mol Life Sci. 2010; 67:545-56. https://doi.org/10.1007/s00018-009-0209-x PMID:20012669

32. Wong RS, Wu A, To KF, Lee N, Lam CW, Wong CK, Chan PK, Ng MH, Yu LM, Hui DS, Tam JS, Cheng G, Sung JJ. Haematological manifestations in patients with severe acute respiratory syndrome: retrospective analysis. BMJ. 2003; 326:1358-62.

https://doi.org/10.1136/bmj.326.7403.1358 PMID: 12816821 
33. Assinger A. Platelets and infection - an emerging role of platelets in viral infection. Front Immunol. 2014; 5:649.

https://doi.org/10.3389/fimmu.2014.00649

PMID:25566260

34. Schafer Al. Thrombocytosis. JAMA. 2015; 314:1171-72. https://doi.org/10.1001/jama.2015.8515 PMID:26372588

35. Harrison CN, Bareford D, Butt N, Campbell P, Conneally $E$, Drummond $M$, Erber W, Everington T, Green AR, Hall GW, Hunt BJ, Ludlam CA, Murrin R, et al, and British Committee for Standards in Haematology. Guideline for investigation and management of adults and children presenting with a thrombocytosis. $\mathrm{Br} J$ Haematol. 2010; 149:352-75.

https://doi.org/10.1111/i.1365-2141.2010.08122.x PMID:20331456

36. Chen R, Sang L, Jiang M, Yang Z, Jia N, Fu W, Xie J, Guan W, Liang W, Ni Z, Hu Y, Liu L, Shan H, et al. Longitudinal hematologic and immunologic variations associated with the progression of COVID-19 patients in China. J Allergy Clin Immunol. 2020; 146:89-100.

https://doi.org/10.1016/j.jaci.2020.05.003 PMID:32407836

37. Yang $X$, Yang $Q$, Wang $Y$, Wu Y, Xu J, Yu Y, Shang Y. Thrombocytopenia and its association with mortality in patients with COVID-19. J Thromb Haemost. 2020; 18:1469-72.

https://doi.org/10.1111/jth.14848

PMID:32302435

38. Williamson DR, Albert M, Heels-Ansdell D, Arnold DM, Lauzier F, Zarychanski R, Crowther M, Warkentin TE, Dodek P, Cade J, Lesur O, Lim W, Fowler R, et al, and PROTECT collaborators, the Canadian Critical Care Trials Group, the Australian and New Zealand Intensive Care Society Clinical Trials Group. Thrombocytopenia in critically ill patients receiving thromboprophylaxis: frequency, risk factors, and outcomes. Chest. 2013; 144:1207-15.

https://doi.org/10.1378/chest.13-0121

PMID:23788287

39. Taylor FB Jr, Toh $\mathrm{CH}$, Hoots WK, Wada H, Levi M, and Scientific Subcommittee on Disseminated Intravascular Coagulation (DIC) of the International Society on Thrombosis and Haemostasis (ISTH). Towards definition, clinical and laboratory criteria, and a scoring system for disseminated intravascular coagulation. Thromb Haemost. 2001; 86:1327-30.

PMID: 11816725

40. Amgalan A, Othman M. Exploring possible mechanisms for COVID-19 induced thrombocytopenia: unanswered questions. J Thromb Haemost. 2020; 18:1514-16. https://doi.org/10.1111/jth.14832
PMID:32278338

41. Levi M, Thachil J, Iba T, Levy JH. Coagulation abnormalities and thrombosis in patients with COVID19. Lancet Haematol. 2020; 7:e438-40. https://doi.org/10.1016/S2352-3026(20)30145-9 PMID: $\underline{32407672}$

42. Panigada M, Bottino N, Tagliabue P, Grasselli G, Novembrino C, Chantarangkul V, Pesenti A, Peyvandi F, Tripodi A. Hypercoagulability of COVID-19 patients in intensive care unit. A report of thromboelastography findings and other parameters of hemostasis. J Thromb Haemost. 2020; 18:1738-42. https://doi.org/10.1111/jth.14850 PMID:32302438

43. Helms J, Tacquard C, Severac F, Leonard-Lorant I, Ohana M, Delabranche X, Merdji H, Clere-Jehl R, Schenck M, Fagot Gandet F, Fafi-Kremer S, Castelain V, Schneider F, et al, and CRICS TRIGGERSEP Group (Clinical Research in Intensive Care and Sepsis Trial Group for Global Evaluation and Research in Sepsis). High risk of thrombosis in patients with severe SARSCoV-2 infection: a multicenter prospective cohort study. Intensive Care Med. 2020; 46:1089-98. https://doi.org/10.1007/s00134-020-06062-x PMID:32367170

44. Spiezia L, Boscolo A, Poletto F, Cerruti L, Tiberio I, Campello E, Navalesi P, Simioni P. COVID-19-related severe hypercoagulability in patients admitted to intensive care unit for acute respiratory failure. Thromb Haemost. 2020; 120:998-1000. https://doi.org/10.1055/s-0040-1710018 PMID:32316063

45. National Health Commission \& National Administration of Traditional Chinese Medicine. Diagnosis and Treatment Protocol for Novel Coronavirus Pneumonia (Trial Version 7). Chin Med J (Engl). 2020; 133:10871095.

https://doi.org/10.1097/CM9.0000000000000819 PMID:32358325

46. Asakura H. Classifying types of disseminated intravascular coagulation: clinical and animal models. J Intensive Care. 2014; 2:20.

https://doi.org/10.1186/2052-0492-2-20 PMID:25520834

47. Sato N, Takahashi $H$, Shibata A. Fibrinogen/fibrin degradation products and d-dimer in clinical practice: interpretation of discrepant results. Am J Hematol. 1995; 48:168-74.

https://doi.org/10.1002/ajh.2830480306

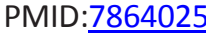

48. Johnson ED, Schell JC, Rodgers GM. The d-dimer assay. Am J Hematol. 2019; 94:833-39.

https://doi.org/10.1002/ajh.25482 
PMID: $\underline{30945756}$

49. Cui S, Chen S, Li X, Liu S, Wang F. Prevalence of venous thromboembolism in patients with severe novel coronavirus pneumonia. J Thromb Haemost. 2020; 18:1421-24.

https://doi.org/10.1111/ith.14830

PMID: $\underline{32271988}$

50. Klok FA, Kruip MJ, van der Meer NJ, Arbous MS, Gommers D, Kant KM, Kaptein FH, van Paassen J, Stals MA, Huisman MV, Endeman H. Confirmation of the high cumulative incidence of thrombotic complications in critically ill ICU patients with COVID-19: an updated analysis. Thromb Res. 2020; 191:148-50.

https://doi.org/10.1016/j.thromres.2020.04.041 PMID:32381264

51. Middeldorp S, Coppens $M$, van Haaps TF, Foppen M, Vlaar AP, Müller MC, Bouman CC, Beenen LF, Kootte RS, Heijmans J, Smits LP, Bonta PI, van Es N. Incidence of venous thromboembolism in hospitalized patients with COVID-19. J Thromb Haemost. 2020; 18:19952002.

https://doi.org/10.1111/jth.14888

PMID:32369666

52. Bermejo-Martin JF, Martín-Fernandez M, LópezMestanza C, Duque P, Almansa R. Shared Features of Endothelial Dysfunction between Sepsis and Its Preceding Risk Factors (Aging and Chronic Disease). J Clin Med. 2018; 7:400.

https://doi.org/10.3390/jcm7110400

PMID:30380785

53. Grimmer B, Kuebler WM. The endothelium in hypoxic pulmonary vasoconstriction. J Appl Physiol (1985). 2017; 123:1635-46.

https://doi.org/10.1152/japplphysiol.00120.2017 PMID:28860164

54. Iba T, Levy JH, Warkentin TE, Thachil J, van der Poll T, Levi $\mathrm{M}$, and Scientific and Standardization Committee on DIC, and the Scientific and Standardization Committee on Perioperative and Critical Care of the International Society on Thrombosis and Haemostasis. Diagnosis and management of sepsis-induced coagulopathy and disseminated intravascular coagulation. J Thromb Haemost. 2019; 17:1989-1994. https://doi.org/10.1111/jth.14578

PMID:31410983

55. Wu YP, Wei R, Liu ZH, Chen B, Lisman T, Ren DL, Han JJ, Xia ZL, Zhang FS, Xu WB, Preissner KT, de Groot PG. Analysis of thrombotic factors in severe acute respiratory syndrome (SARS) patients. Thromb Haemost. 2006; 96:100-1.

https://doi.org/10.1160/TH05-12-0827

PMID:16807662
56. Levi M, Meijers JC. DIC: which laboratory tests are most useful. Blood Rev. 2011; 25:33-37. https://doi.org/10.1016/j.blre.2010.09.002 PMID:20950905

57. Kienast J, Juers M, Wiedermann CJ, Hoffmann JN, Ostermann H, Strauss R, Keinecke HO, Warren BL, Opal SM, and KyberSept investigators. Treatment effects of high-dose antithrombin without concomitant heparin in patients with severe sepsis with or without disseminated intravascular coagulation. J Thromb Haemost. 2006; 4:90-7. https://doi.org/10.1111/i.1538-7836.2005.01697.x PMID: 16409457

58. Dhainaut JF, Yan SB, Joyce DE, Pettilä V, Basson B, Brandt JT, Sundin DP, Levi M. Treatment effects of drotrecogin alfa (activated) in patients with severe sepsis with or without overt disseminated intravascular coagulation. J Thromb Haemost. 2004; 2:1924-33. https://doi.org/10.1111/j.1538-7836.2004.00955.x PMID:15550023

59. Gando S, Iba T, Eguchi Y, Ohtomo Y, Okamoto K, Koseki K, Mayumi T, Murata A, Ikeda T, Ishikura H, Ueyama M, Ogura $\mathrm{H}$, Kushimoto $\mathrm{S}$, et al; and Japanese Association for Acute Medicine Disseminated Intravascular Coagulation (JAAM DIC) Study Group. A multicenter, prospective validation of disseminated intravascular coagulation diagnostic criteria for critically ill patients: comparing current criteria. Crit Care Med. 2006; 34:625-31.

https://doi.org/10.1097/01.ccm.0000202209.42491.38 PMID: 16521260

60. Tang N, Bai H, Chen X, Gong J, Li D, Sun Z. Anticoagulant treatment is associated with decreased mortality in severe coronavirus disease 2019 patients with coagulopathy. J Thromb Haemost. 2020; 18:1094-1099.

https://doi.org/10.1111/ith.14817

PMID:32220112

61. Lodigiani C, lapichino G, Carenzo L, Cecconi M, Ferrazzi P, Sebastian T, Kucher N, Studt JD, Sacco C, Alexia B, Sandri MT, Barco S; Humanitas COVID-19 Task Force. Venous and arterial thromboembolic complications in COVID-19 patients admitted to an academic hospital in Milan, Italy. Thromb Res. 2020; 191:9-14. https://doi.org/10.1016/i.thromres.2020.04.024 PMID: $\underline{32353746}$

62. Llamas-Velasco $M$, Muñoz-Hernández $P$, LázaroGonzález J, Reolid-Pérez A, Abad-Santamaría B, Fraga J, Daudén-Tello $E$. Thrombotic occlusive vasculopathy in skin biopsy from a livedoid lesion of a patient with COVID-19. Br J Dermatol. 2020; 10:1111. https://doi.org/10.1111/bjd.19222 PMID:32407552 
63. Llitjos JF, Leclerc $M$, Chochois C, Monsallier JM, Ramakers M, Auvray M, Merouani K. High incidence of venous thromboembolic events in anticoagulated severe COVID-19 patients. J Thromb Haemost. 2020; 18:1743-46.

https://doi.org/10.1111/jth.14869

PMID:32320517

64. Ranucci M, Ballotta A, Di Dedda U, Bayshnikova E, Dei Poli M, Resta M, Falco M, Albano G, Menicanti L. The procoagulant pattern of patients with COVID-19 acute respiratory distress syndrome. J Thromb Haemost. 2020. 18:1747-51.

https://doi.org/10.1111/ith.14854

PMID:32302448

65. Zhang L, Feng $X$, Zhang $D$, Jiang $C$, Mei $H$, Wang J, Zhang C, Li H, Xia X, Kong S, Liao J, Jia H, Pang X, et al. Deep vein thrombosis in hospitalized patients with coronavirus disease 2019 (COVID-19) in Wuhan, China: prevalence, risk factors, and outcome. Circulation. 2020. [Epub ahead of print].

https://doi.org/10.1161/CIRCULATIONAHA.120.046702 PMID:32421381

66. Lin L, Lu L, Cao W, Li T. Hypothesis for potential pathogenesis of SARS-CoV-2 infection-a review of immune changes in patients with viral pneumonia. Emerg Microbes Infect. 2020; 9:727-732.

https://doi.org/10.1080/22221751.2020.1746199

PMID:32196410

67. Liberati A, Altman DG, Tetzlaff J, Mulrow C, Gøtzsche PC, loannidis JP, Clarke M, Devereaux PJ, Kleijnen J, Moher D. The PRISMA statement for reporting systematic reviews and meta-analyses of studies that evaluate healthcare interventions: explanation and elaboration. BMJ. 2009; 339:b2700.

https://doi.org/10.1136/bmj.b2700

PMID:19622552

68. Stang A. Critical evaluation of the Newcastle-Ottawa scale for the assessment of the quality of nonrandomized studies in meta-analyses. Eur J Epidemiol. 2010; 25:603-05.

https://doi.org/10.1007/s10654-010-9491-z

PMID:20652370

69. Higgins JP, Thompson SG, Deeks JJ, Altman DG. Measuring inconsistency in meta-analyses. BMJ. 2003; 327:557-60. https://doi.org/10.1136/bmj.327.7414.557 PMID:12958120 


\section{SUPPLEMENTARY MATERIALS}

\section{Supplementary Figures}

A

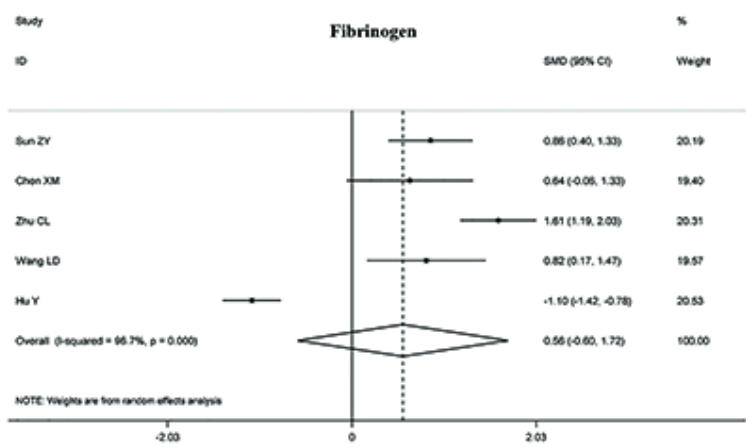

C

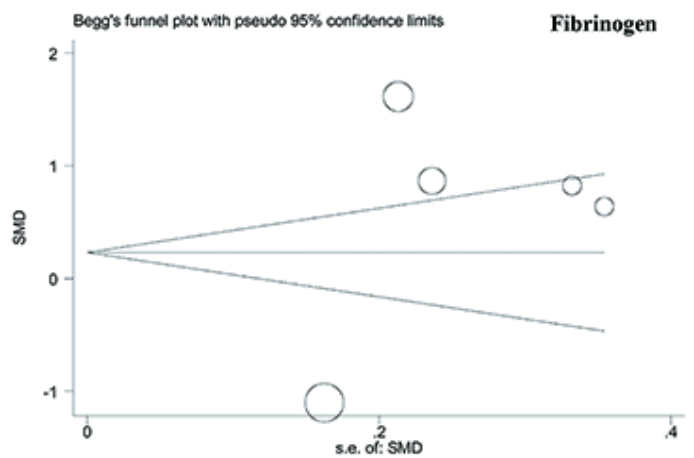

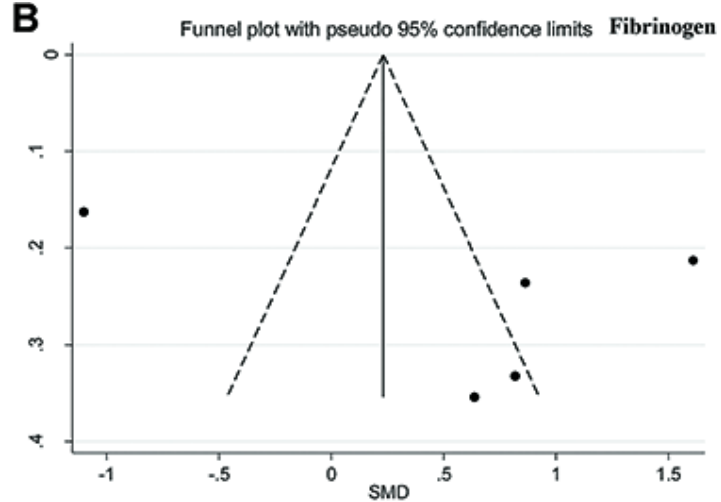

D

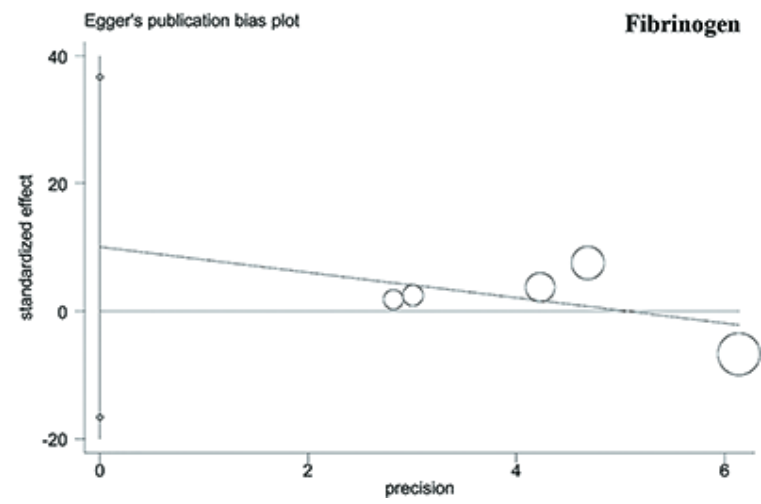

Supplementary Figure 1. Forest plots and publication bias of fibrinogen. Forest plots of pooled standard mean difference and $95 \%$ $\mathrm{Cls}$ assessing the severity status of COVID-19 patients by fibrinogen. The sizes of the blocks or diamonds represent the weights, and the lengths of the straight lines represent the widths of the $95 \% \mathrm{Cl}$ (A) Funnel plot (B) Egger's test (C) and Begg's (D) test assessing the publication bias of fibrinogen.

A

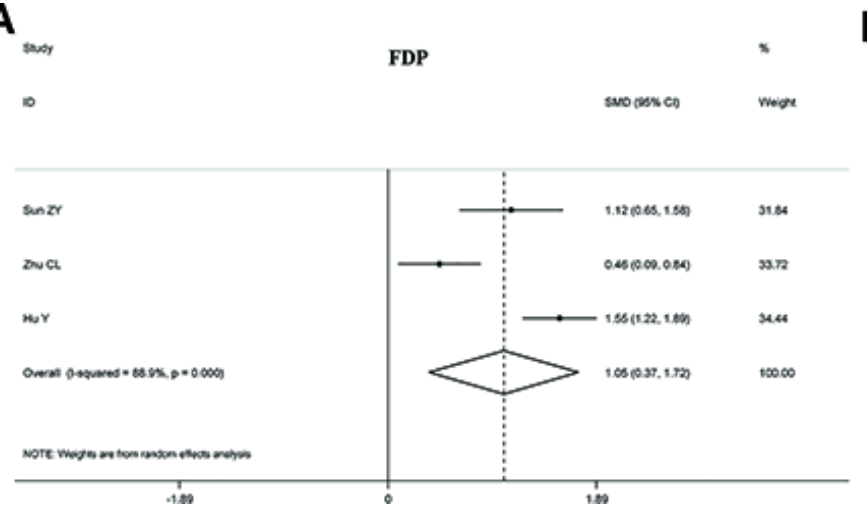

B

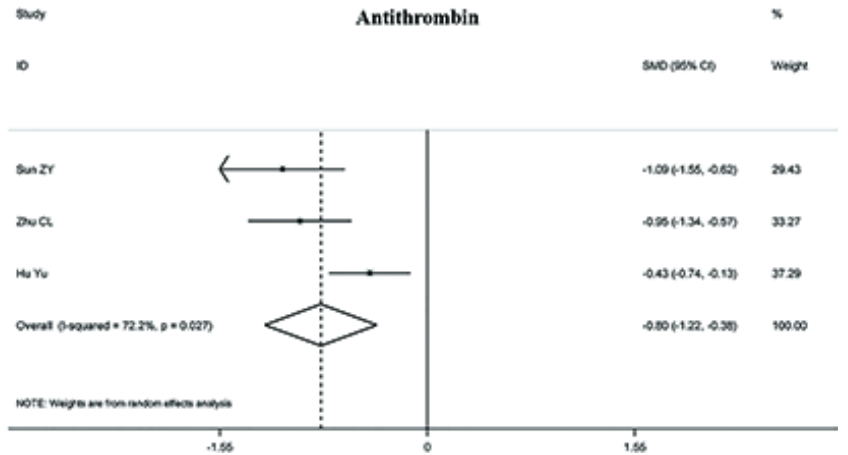

Supplementary Figure 2. Forest plots of pooled standard mean difference and $95 \% \mathrm{Cls}$ assessing the severity status of COVID-19 patients by fibrin/fibrinogen degradation products (FDP) (A) and antithrombin (B). The sizes of the blocks or diamonds represent the weights, and the lengths of the straight lines represent the widths of the $95 \%$ Cls. 

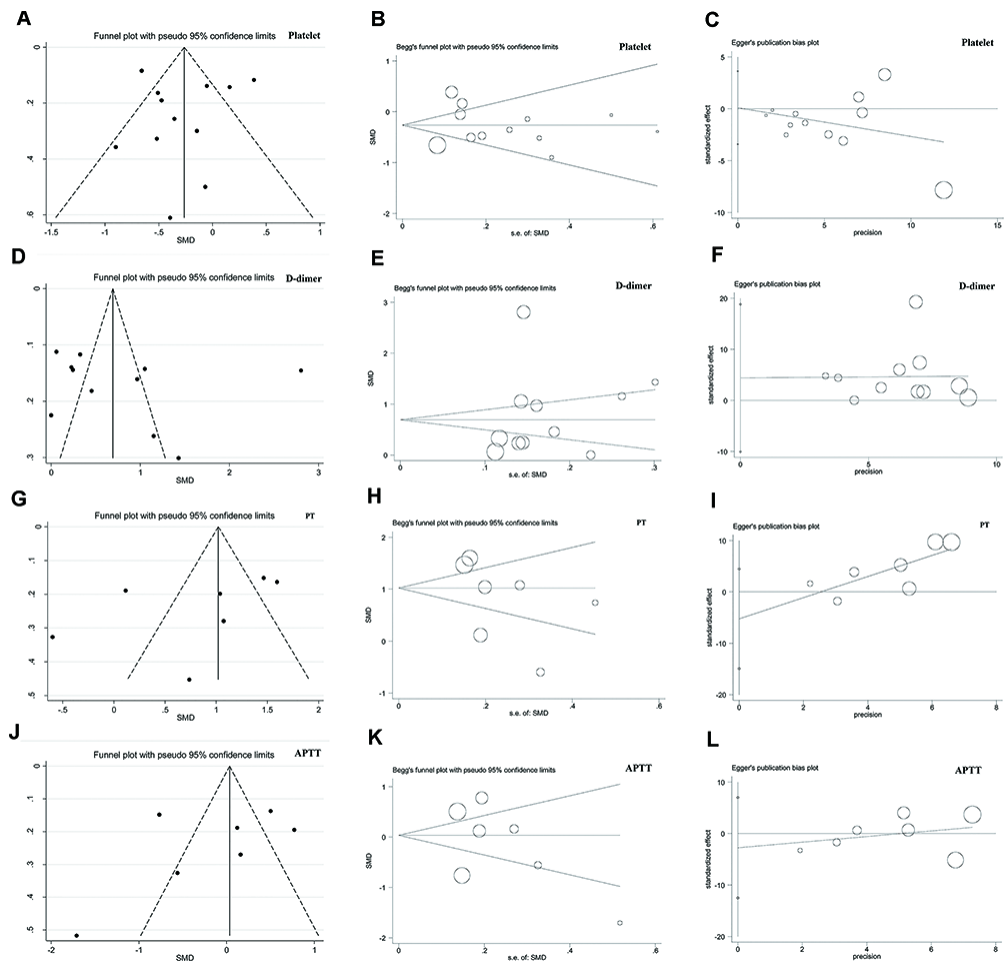

Supplementary Figure 3. Funnel plot, Egger's test and Begg's test assessing the publication bias of platelet (A-C) D-dimer (D-F) prothrombin time (PT) (G-I) and activated partial thromboplastin time (APTT) (J-L) associated with the severity status, respectively.
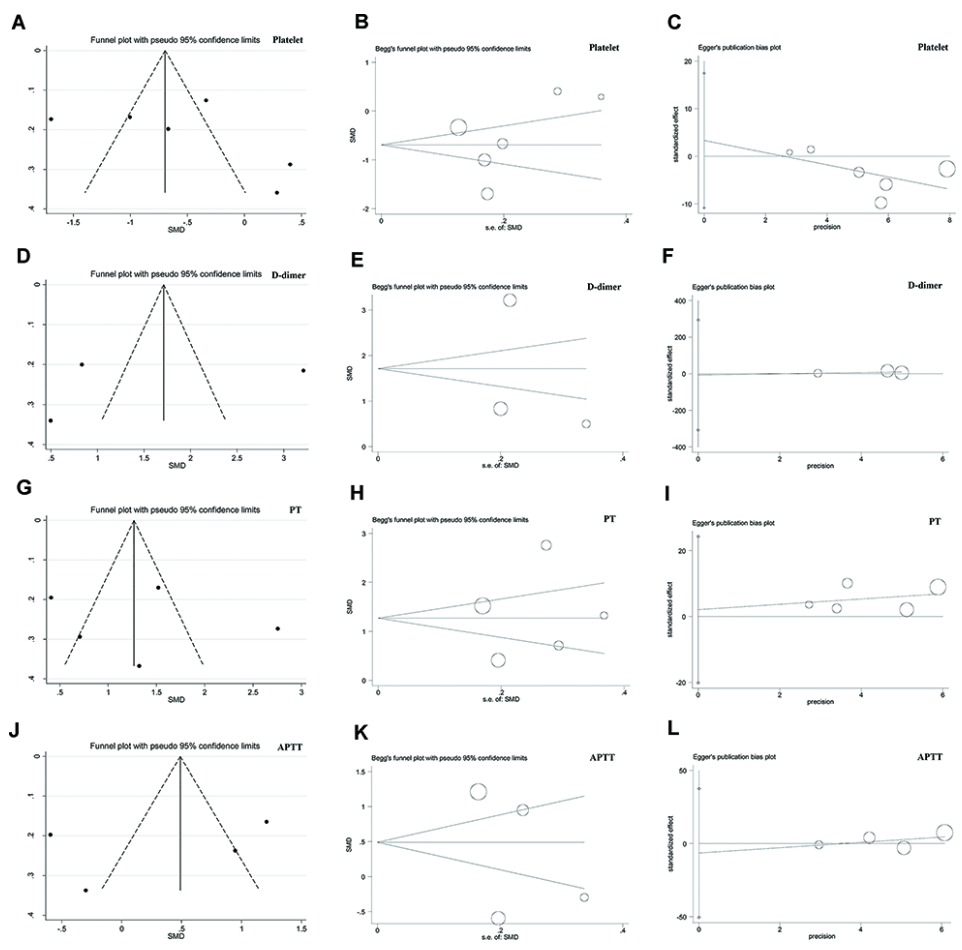

Supplementary Figure 4. Funnel plot, Egger's test and Begg's test assessing the publication bias of platelet (A-C) D-dimer (D-F) prothrombin time (PT) $(\mathbf{G}-\mathbf{I})$ and activated partial thromboplastin time (APTT) (J-L) associated with the composite endpoint, respectively. 
A

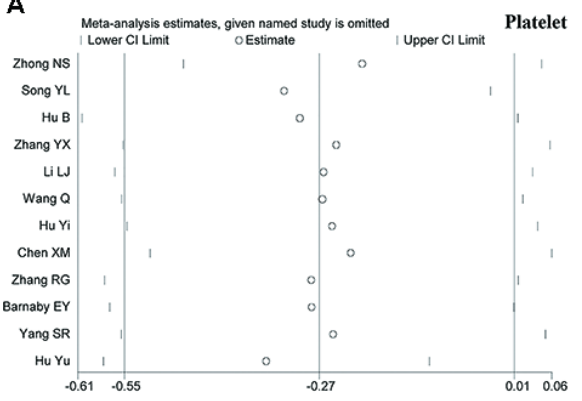

C

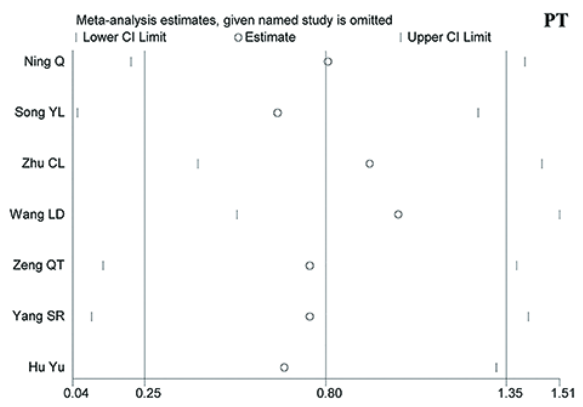

B

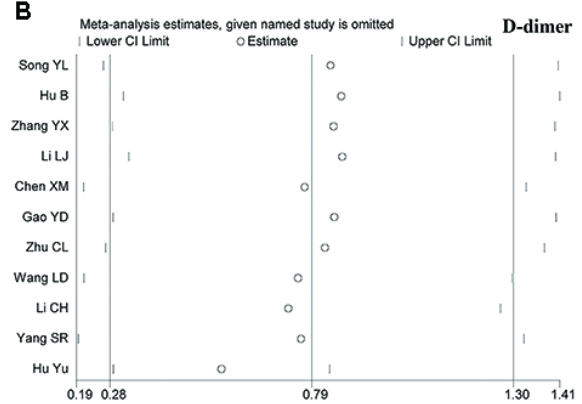

D

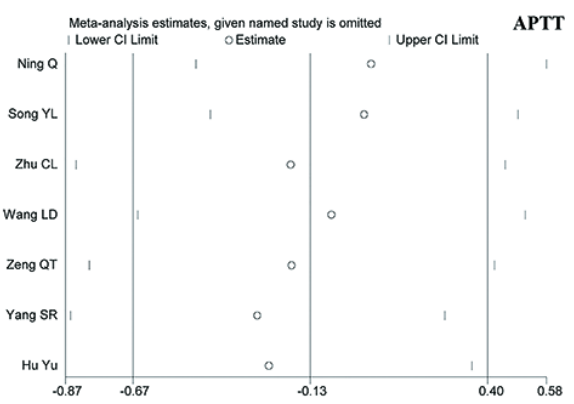

Supplementary Figure 5. Sensitivity analysis of studies involving platelet (A) D-dimer (B) prothrombin time (PT) (C) and activated partial thromboplastin time (APTT) (D) associated with the severity status. None of the articles removed would have a significant effect on the results.

A

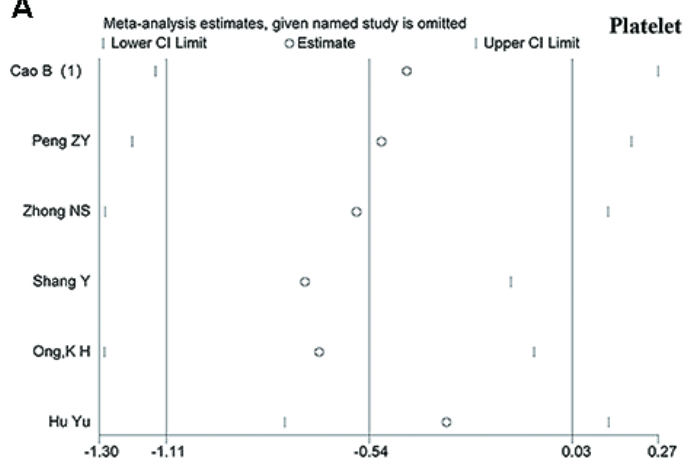

C

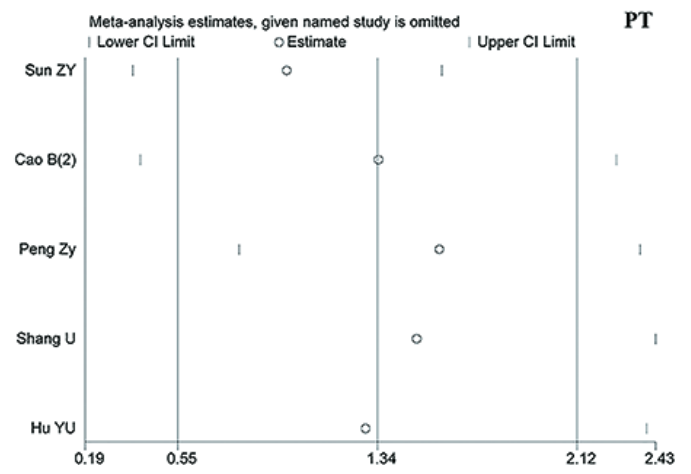

B

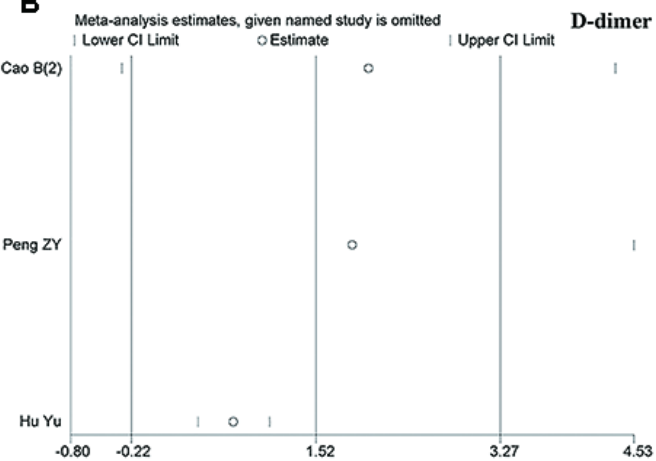

D

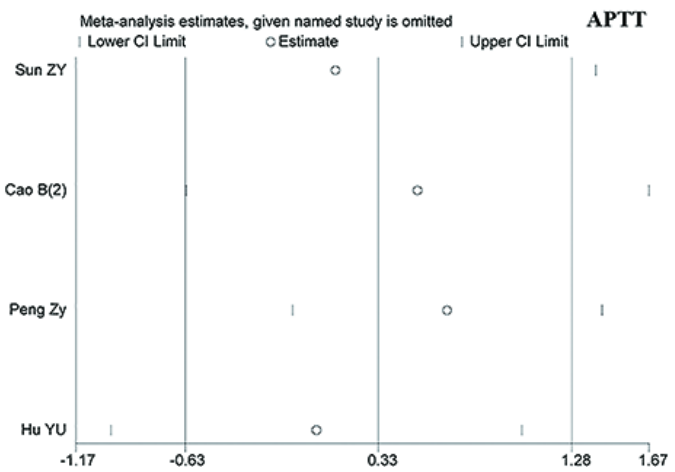

Supplementary Figure 6. Sensitivity analysis of studies involving platelet (A) D-dimer (B) prothrombin time (PT) (C) and activated partial thromboplastin time (APTT) (D) associated with the composite endpoint. None of the articles removed would have a significant effect on the results. 


\section{Supplementary Tables}

Supplementary Table 1. Newcastle-Ottawa quality assessment scale (NOS).

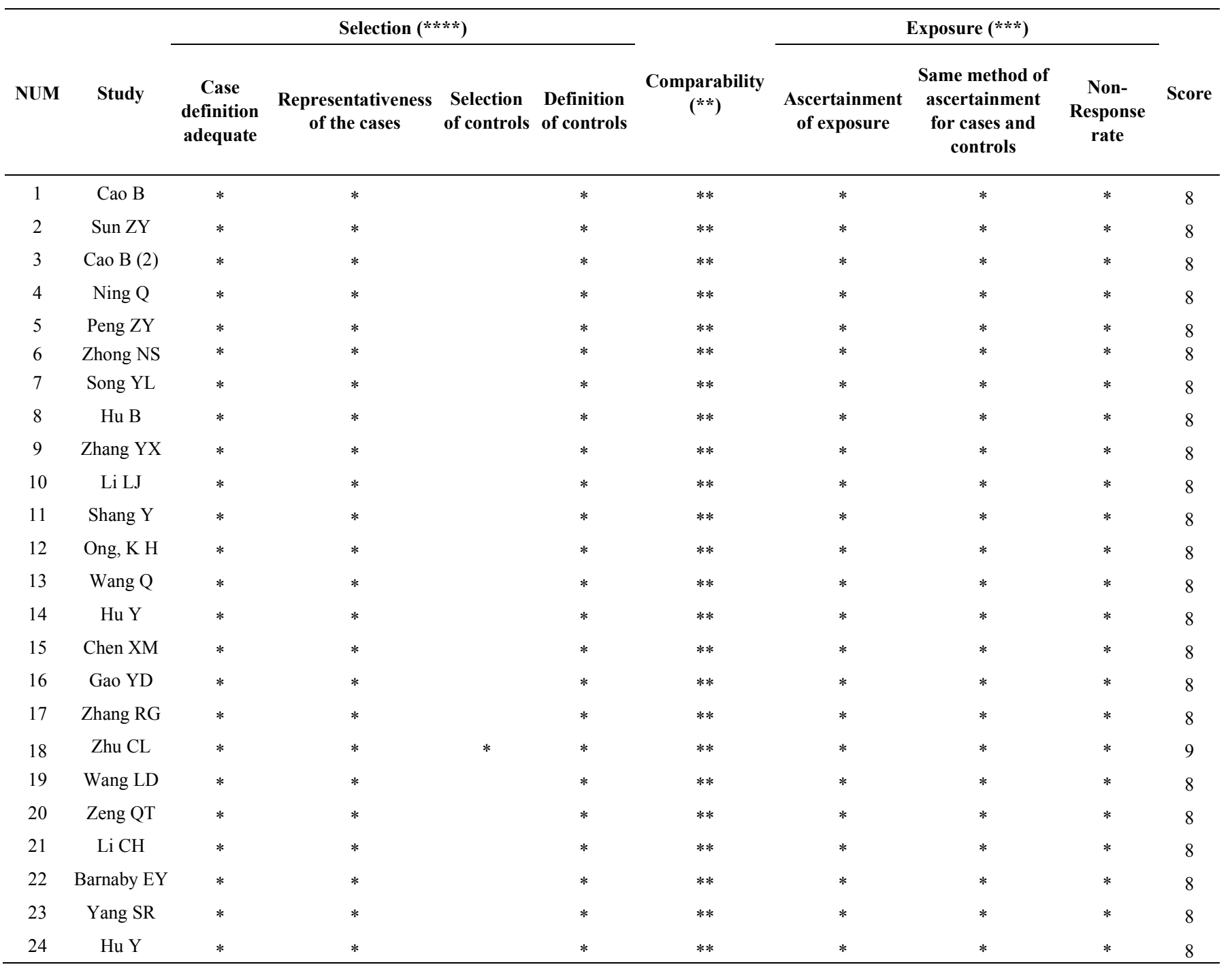




\section{Supplementary Table 2. Research strategy.}

\begin{tabular}{|c|c|}
\hline \multirow[t]{5}{*}{ PubMed } & $\begin{array}{l}\text { Mesh: severe acute respiratory syndrome coronavirus } 2 \text { COVID-19; spike glycoprotein; COVID-19 } \\
\text { virus }\end{array}$ \\
\hline & $\begin{array}{l}\text { Entry Terms: Wuhan coronavirus; Wuhan seafood market pneumonia virus; COVID19 virus; } \\
\text { coronavirus disease } 2019 \text { virus; SARS-CoV-2; SARS2; 2019-nCoV; } 2019 \text { novel coronavirus; }\end{array}$ \\
\hline & 2019 novel coronavirus infection; COVID19; coronavirus disease 2019; coronavirus disease-19; \\
\hline & $\begin{array}{l}\text { 2019-nCoV disease; } 2019 \text { novel coronavirus disease; } 2019-n C o V \text { infection; COVID-19 virus spike } \\
\text { glycoprotein; 2019-nCoV spike glycoprotein }\end{array}$ \\
\hline & $\begin{array}{l}\text { Search }((((()((()(()((((\text { severe acute respiratory syndrome coronavirus 2) OR COVID-19) OR spike } \\
\text { glycoprotein, COVID-19 virus) OR Wuhan coronavirus) OR Wuhan seafood market pneumonia } \\
\text { virus) OR COVID19 virus) OR coronavirus disease 2019 virus) OR SARS-CoV-2) OR SARS2) OR } \\
\text { 2019-nCoV) OR 2019 novel coronavirus) OR } 2019 \text { novel coronavirus infection) OR COVID19) OR } \\
\text { coronavirus disease 2019) OR coronavirus disease-19) OR 2019-nCoV disease) OR 2019 novel } \\
\text { coronavirus disease) OR 2019-nCoV infection) OR COVID-19 virus spike glycoprotein) OR 2019- } \\
\text { nCoV spike glycoprotein }\end{array}$ \\
\hline Web of Science & $\begin{array}{l}\text { TS=(severe acute respiratory syndrome coronavirus2 OR COVID-19 OR spike glycoprotein, } \\
\text { COVID-19 virus OR Wuhan coronavirus OR Wuhan seafood market pneumonia virus OR COVID19 } \\
\text { virus OR coronavirus disease } 2019 \text { virus OR SARS-CoV-2 OR 2019-nCoV OR } 2019 \text { novel } \\
\text { coronavirus OR } 2019 \text { novel coronavirus infection OR COVID19 OR coronavirus disease } 2019 \text { OR } \\
\text { coronavirus disease-19 OR 2019-nCoV disease OR } 2019 \text { novel coronavirus disease OR 2019-nCoV } \\
\text { infection OR COVID-19 virus spike glycoprotein OR 2019-nCoV spike glycoprotein) }\end{array}$ \\
\hline $\begin{array}{l}\text { Cochrane Library } \\
\text { Scopus }\end{array}$ & $\begin{array}{l}\text { We put "COVID-19" into the Mesh box, but no Mesh terms and Tree were available } \\
\text { Search ("severe acute respiratory syndrome coronavirus2") OR (COVID-19) OR ("spike } \\
\text { glycoprotein, COVID-19 virus") OR ("Wuhan coronavirus")OR("Wuhan seafood market pneumonia } \\
\text { virus ")OR(" COVID19 virus") OR ("coronavirus disease } 2019 \text { virus ")OR ("SARS-CoV-2") OR } \\
\text { ("2019-nCoV ")OR ("2019 novel coronavirus") OR ("2019 novel coronavirus infection") OR } \\
\text { (COVID19) OR ("coronavirus disease 2019") OR ("coronavirus disease-19") OR ("2019-nCoV } \\
\text { disease ")OR ("2019 novel coronavirus disease") OR ("2019-nCoV infection") OR ("COVID-19 } \\
\text { virus spike glycoprotein") OR ("2019-nCoV spike glycoprotein") }\end{array}$ \\
\hline
\end{tabular}

